\title{
Productivity and Physiological Response of Fodder Beet to Drip Irrigation Regimes and Potassium Levels Under Calcareous Soil Conditions
}

\author{
Mofeeda A. Seiam ${ }^{1}$, Mary E. Nashed ${ }^{2}$, Osman A M $^{3}$ and M.A. Sayed ${ }^{3}$ \\ 1-Forage Crops Res. Department, field crop institute, A.R.C, Egypt Email, Mofedaseiam @ \\ yahoo. Com. \\ 2-Crop physiology Res .Department, Field crops institute, A.R.C., Egypt Email, \\ nashed.henen.4@Gmail.Com. \\ 3- Water Requirements \& field irrigation Dept., Soil, water and Environment RES. Institute. \\ ARC, Egypt.
}

\begin{abstract}
A field trait was conducted at Nubaria Agricultural Research Station, EL-Behira Governorate, Egypt during two winter successive growing seasons of 2013/2014 and 2014/2015 on fodder beet (Beta vulgaris L.) variety Voroshenger. The aim was to study the effect of three drip irrigation regimes i.e. Irrigation with amount of water equal $100 \%$ (I1), 80\% (I2) and $60 \%$ ( I3) of potential evapotranspiration (ETp) and potassium fertilization at rates of 0 , $57.12,114.24$ and $171.36 \mathrm{Kg} \mathrm{K} 2 \mathrm{O} / \mathrm{ha}$.

Results of combining analysis revealed that increasing irrigation levels led to significant increase in crop growth rate (CGR) at (90-120) and (120-150) DAS, leaves and root fresh weight $\mathrm{Kg} / \mathrm{plant}$, leaves and root dry weight $\mathrm{g} / \mathrm{plant}$, root length and diameter as well as root, total yield ton/ha and total chlorophyll of leaves. Dry treatments significantly reduced the percentage of potassium $(\mathrm{K} \%)$, crud protein $(\mathrm{CP} \%)$, digestive crud protein (DCP \%) and crud fiber (CF \%). Whereas, the percentage of total soluble solid (TSS \%) and total digestible nutrients (TDN \%) significantly increased. The maximum percentage of Relative water content (RWC \%) was obtained from wet treatment, while medium treatment at $80 \%$ of ETp give the maximum values of water utilization efficiency (WUtE).

Adding $171.36 \mathrm{KgK}_{2} \mathrm{O} / \mathrm{ha}$ significantly increased CGR at (90-120) and (120-150) DAS, Leaves fresh weight $\mathrm{Kg} / \mathrm{plant}$, leaves and root dry weight, root length and diameter, root and foliage yields as well as total yield ton/ha, total chlorophyll of leaves, DCP\% and $\mathrm{K} \%$. While adding 171.36 and $114.3 \mathrm{KgK}_{2} \mathrm{O} /$ ha significantly increased root fresh weight $\mathrm{Kg} / \mathrm{plant}, \mathrm{CP} \%$ and $\mathrm{CF} \%$ with insignificant difference. However, TDN\% decreased by increasing potassium fertilization. Maximum RWC\% and WUtE were obtained when plants received $171.36 \mathrm{KgK} 2 \mathrm{O} / \mathrm{ha}$.

The interaction between irrigation regimes and potassium fertilization levels had significant effect on all traits under study except CGR at (90-120) DAS, root diameter, foliage yield ton/fed, total chlorophyll of leaves, K\% and TSS\%. The highest values of CGR (120-190), Leaves Fresh weight $\mathrm{Kg} / \mathrm{plant}$, leaves and root dry weight g/plant, $\mathrm{CP} \%, \mathrm{CF} \%$ as well as DCP\% and RWC were achieved from wet treatment (100\% of ETp) in combination with $171.36 \mathrm{KgK}_{2} \mathrm{O} / \mathrm{ha}$. While irrigation with $100 \%, 80 \%$ of ETp and $171.36 \mathrm{KgK}_{2} \mathrm{O} /$ ha gave the highest values for root length, root and total yield ton/ha as well as WUtE with insignificant difference. However irrigation with $100 \%$ of ETp combined with 114.24 and 171.36 have the highest values for root fresh weight $\mathrm{Kg} /$ plant with insignificant difference. The maximum TDN\% obtained from dry treatment (60\% of ETp) without potassium fertilization.

According to profitability assessment, the highest net income and investment ratio as an average of two growing seasons were obtained when plants watered by amount of water equal $80 \%$ of ETp and received $171.36 \mathrm{KgK}_{2} \mathrm{O} / \mathrm{ha}$.
\end{abstract}

Keywords: Fodder beet- Regime irrigation- Potassium levels- Growth- Forage yields and quality- Water utilization efficiency.

\section{INTRODUCTION}

Fodder beet (Beta vulgaris, L) is one of the most promising winter forage crop in Egypt. It is and ideal fodder for dairy cows due to its high nutritive value, high dry matter yield, good source of carbohydrates, high palatability and digestibility. Moreover, it is adapted to saline, calcareous soils and requires less water compared to other forage crops. The whole yield, i.e; above and underground parts, can directly be used in feedings, or may be processed as silage. The roots can also be stored in soil without great damage. Thus, its cultivation may help in overcoming the problem of animal feeding during summer season.

Water stress is a major condition that affect crop productivity. Water is an integral part of plant, plays a vital role in the maintenance of plant life. The deficiency of water modifies soil-plant water relationship by lowering tissue water potential and impairing metabolic processes, (Akhtar et al 1993). Currently, water is a primary limiting factor in Egyptian agriculture to address efforts to the fundamental issue of increasing crops production, while reducing their water consumption, especially in reclaimed lands. This might be achieved through an effective use of modern irrigation techniques. Several investigation studied the effect of water stress on fodder beet growth. Hussein and Siam, Hanan (2014) pointed that the least fresh roots or tops yields were obtained when plants subjected to drought by withholding the $2^{\text {nd }}$ irrigation, while, the least tops, roots and total dry yields were obtained when plants subjected to drought by withholding the $4^{\text {th }}$ irrigation. Also, Sakr et al (2014) 
stated that, water stress during maturity stage through withholding last, two or last three irrigation markedly reduced forage yields and its components as well as crude protein $(\mathrm{CP} \%)$, crude fiber( $\mathrm{CF} \%)$, potassium $(\mathrm{K} \%)$ and digestible crude protein $(\mathrm{DCP} \%)$. In contrary, gradual increases in total soluble solids (TSS $\%)$ and total digestible nutrients (TDN \%) were resulted from irrigation withholding treatments.

With increasing demands on limited water resources and the need to minimize adverse environmental consequences of irrigation, drip irrigation technology will undoubtedly play an important role in the future of the Egyptian agriculture. Application of uniform and sufficient water for good crop establishment is one of the most challenge issues of subsurface drip irrigation (Camp, 1998).

Most cultivated crops experience one or more abiotic stresses of some type throughout their growth stages. Thus, increasing plant resilience in response to abiotic stress is great challenge in the effort to improve plant production. Improving plant tolerance to drought is achieved by applying potassium which is vital for plant survival under water stress conditions. Moreover, potassium plays significant regulatory roles in osmoregulation, water movement, cationanion balance, enzymatic activation, as well as activating antioxidant defense system.

A close relationship between the potassium nutritional status and fodder beet plant drought resistance has been demonstrated. Bahuri, et al (2003). They studied the effect of different irrigation water and different potassium levels on fodder beet yield and yield components in sandy soil under drip irrigation. Results showed that, fodder beet yield increased by increasing irrigation water and potassium rats. The fresh roots yield increased by 17.1 and $19.8 \%$ with increasing applied water to 2300 and 2760 $\mathrm{m}^{3} /$ fed., respectively compared with $1840 \mathrm{~m}^{3} / \mathrm{fed}$. Potassium fertilizer mitigates the adverse effects of drought on plant growth. Kassab et al, 2012, suggested that foliar potassium $(\mathrm{K})$ spray of $1 \mathrm{Kg} / \mathrm{fed}$ gave the highest values of growth and yield parameters as well as water use efficiency (WUE) in both seasons. Also, the interaction between irrigation regimes and $\mathrm{K}$ fertilizer was significant in most growth and yield parameters.

The present investigation was carried out to study the physiological response of fodder beet plant to three drip irrigation water regimes in combination with different levels of potassium fertilization on growth, productivity, forage quality, as well as water utilization efficiency under calcareous soils conductions of Nubaria region.

\section{MATERIALS AND METHODS}

A field experiments was conducted during the two successive winter seasons of 2013/2014 and 2014/2015 at Nubaria Agricultural Research Station, EL-Behiera governorate, Egypt, using fodder beet variety Voroshenger to study the effect of surface drip irrigation and potassium fertilization levels and their interaction on growth, productivity and forage quality. The experiment was laid out in a strip-plot design with three replicates. The vertical plots were assigned to three irrigation treatments and the horizontal plots were occupied by four potassium fertilization rates. The used surface drip irrigation system in the experimental farm included an irrigation pupm connected to sand and screen filters and a fertilizer injector tank. Main line is made of PVC pipe of $63 \mathrm{~mm}$ diameter, while drip lateral lines of $16 \mathrm{~mm}$ diameter were connected to the main lines. Each lateral is $25 \mathrm{~m}$ long and $0.5 \mathrm{~m}$ spacing. Standard emitters of $4.0 \mathrm{~L} / \mathrm{h}$ discharge were spaced $0.3 \mathrm{~m}$ apart on the lateral line. Each experimental plot contend four lateral lines. Drip irrigation efficiency parameters including Christiansen coefficient and emission uniformity were determined. The values of these parameters were $94 \%$ and $92 \%$ respectively. The measured emitter average discharge rate was $3.52 \mathrm{~L} / \mathrm{h}$. Fodder beet seeds were planted on $30^{\text {th }}$ October, 2013 and $13^{\text {th }}$ October, 2014 in the first and second seasons, respectively. Plants were thinned to one plant per hill after 30 days from sowing. Mono super phosphate $15.5 \% \quad \mathrm{P}_{2} \mathrm{O}_{5}$ was added at the rate of $71.4 \mathrm{Kg} \mathrm{P}_{2} \mathrm{O} 5 / \mathrm{ha}$ and incorporate to soil before sowing. All plots received $142.8 \mathrm{Kg}$ nitrogen $(\mathrm{N}) /$ ha (as ammonium nitrate, 33.5\% N) through the irrigation system (Fertigation). Also potassium fertilizer levels $(0,57.12,114.24$ and 171.36 $\mathrm{Kg} / \mathrm{ha})$ in the form of potassium sulphate $(48 \%$ $\mathrm{K}_{2} \mathrm{O}$ ) were injected. The irrigation treatments were: $100 \%, 80 \%$ and $60 \%$ of potential evapotranspiration $\left(\mathrm{ET}_{\mathrm{P}}\right)$ and determined by class a pan. To determine growth traits, five plants were randomly taken from each plot at 90, 120 and 150 days from sowing (DAS). In each sample, plants were separated to their components i.e.; leaves and roots, then dried at $60^{\circ} \mathrm{C}$ for $48 \mathrm{~h}$ in a ventilated oven or until constant weight to determine crop growth rate (CGR) at (90-120) and (120-150) DAS in $\mathrm{g} /$ plant/week according to Watson (1952)

\section{Calculated as: $\mathbf{C G R}=\left(\mathbf{W}_{\mathbf{2}}-\mathrm{W}_{\mathbf{1}}\right) /\left(\mathbf{T}_{\mathbf{2}}-\mathbf{T}_{\mathbf{1}}\right)$}

Where; $\left(\mathrm{W}_{2}-\mathrm{W}\right)_{1}=$ differences in dry mater accumulation between two successive samples in grams and $\left(\mathrm{T}_{2}-\mathrm{T}_{1}\right)=$ the number of days between two successive samples in week.

At 100 DAS total chlorophyll of leaves $\left(\mathrm{mg} / \mathrm{m}^{2}\right)$ was determined as SPAD unit using SPAD 502 apparatus (Soil and plant Analysis Departments of Minolta Co.) This unit was transformed to $\mathrm{mg} / \mathrm{m}^{2}$ as described by Mong and Bugbe (1992) as follows:

\section{Chl. $=80.05+10.4($ SPAD 502)}

At harvest (200-202 days from sowing) ten guarded plants were randomly chosen from each plot to determine root length/plant $(\mathrm{cm})$, root diameter/ plant $(\mathrm{cm})$, root fresh weight $(\mathrm{Kg} /$ plant $)$, 
foliage fresh weight ( $\mathrm{Kg} / \mathrm{plant})$, root yield (ton/ha), foliage yield (ton/ha) and total yield (ton/ha). Total soluble solids (TSS \%) in roots was measured in juice of fresh roots by using Hand Refract meter. Roots samples were chopped into 1$2 \mathrm{~cm}$ pieces and thoroughly mixed, a $300 \mathrm{~g}$ sample of fresh chopped roots was dried in an oven at $40^{\circ} \mathrm{C}$ for 2 days and at $70^{\circ} \mathrm{C}$ for 3 days. The dried samples were chemically analyzed for crude protein $(\mathrm{CP} \%)$ and crude fiber ( $\mathrm{CF} \%)$ according to A.O.A.C., 1990. Potassium content in roots was determined using flame photometer as described by Peterburgski (1968). Digestible crude protein (DCP \%) and total digestible nutrients (TDN \%) were calculated according to Church (1979).At 100 days after sowing, leaf samples were immediately weighed (fresh weight, $(\mathrm{Fw})$ ) and transferred into sealed flasks, then rehydrated in water for $5 \mathrm{~h}$ until fully turgid, surface swabbed and reweighed (turgid weight, (Tw)). Leaf samples were oven dried at 70C for $48 \mathrm{~h}$ and reweighed (dry weight, (Dw)). Relative water content (RWC) of leaves (\%) was calculated according to Lazcano-Ferrat and Lovatt (1999) as follows:

\section{RWC \%=( (Fw - Dw $) /($ Tw - Dw $))$ X (100)}

Soil chemophysical characters of the experimental site were determined according to Black (1965). Soil texture for the surface $0-60 \mathrm{~cm}$. depth was sandy clay loam $(60 \%$ sand, $19.1 \%$ silt and $20.9 \%$ clay), soil $\mathrm{pH}=8.4$, O.M. $=0.3 \%$, total $\mathrm{CaCO} 3 \%=31.8 \%, \quad \mathrm{EC}=1.341 \mathrm{ds} \mathrm{m}^{-1}$. Soil baulk density $(\mathrm{BD})=1.21 \mathrm{~g} / \mathrm{cm}^{3}$. Soil field capacity (F.C) and wilting points (WP) were determined by a pressure extractor apparatus (LAB 023 LABORATORY) and available soil moisture (ASM) values were calculated and presented in Table (1).

Table 1: Field capacity, wilting point, available water and soil bulk density a mean of the two experimental seasons at Nuburia Agric. Res - Station farm.

\begin{tabular}{|l|c|c|c|c|}
\hline \multicolumn{1}{|c|}{ Soil depth $(\mathbf{c m})$} & $\begin{array}{c}\text { Field capacity } \\
(\mathbf{\%})\end{array}$ & $\begin{array}{c}\text { Wilting points } \\
(\mathbf{\%})\end{array}$ & $\begin{array}{c}\text { Available water } \\
(\mathbf{\%})\end{array}$ & $\begin{array}{c}\text { Bulk density } \\
\left(\mathbf{g} / \mathbf{c m}^{\mathbf{3}}\right)\end{array}$ \\
\hline $0-15$ & 24.6 & 13.53 & 11.37 & 1.17 \\
\hline $15-30$ & 24.7 & 13.42 & 11.28 & 1.20 \\
\hline $30-45$ & 23.9 & 12.99 & 10.91 & 1.22 \\
\hline $45-60$ & 23.6 & 12.83 & 10.77 & 1.25 \\
\hline Means & 24.27 & 13.19 & 11.08 & 1.21 \\
\hline
\end{tabular}

Monthly potential evapotranspiration $\left(\mathrm{ET}_{\mathrm{P}}\right)$ values measured by class a pan at the experimental site for the $I_{1}\left(100 \% \mathrm{ET}_{\mathrm{P}}\right)$ irrigation treatment and ly $\mathrm{ET}_{\mathrm{P}}$ values started low during December, January and February and increased to maximum values during May for the both seasons. presented in Table (2). Results showed that month-

Table 2: Potential evapotranspiration ETp (mm/month) and (mm/day). Values for the 2013/14and 2014/15seasons

\begin{tabular}{|l|c|c|c|c|}
\hline \multirow{2}{*}{ Month } & \multicolumn{2}{|c|}{$\mathbf{2 0 1 3 / 1 4}$} & \multicolumn{2}{c|}{$\mathbf{2 0 1 4 / 1 5}$} \\
\cline { 2 - 5 } & $\mathbf{m m} / \mathbf{m o n t h}$ & $\mathbf{m m} / \mathbf{d a y}$ & $\mathbf{m m} / \mathbf{m o n t h}$ & $\mathbf{m m} / \mathbf{d a y}$ \\
\hline Oct. & - & - & 64.6 & 2.08 \\
\hline Nov. & 59.1 & 1.97 & 72.0 & 2.40 \\
\hline Dec. & 46.5 & 1.50 & 55.8 & 1.8 \\
\hline Jan. & 38.75 & 1.25 & 46.5 & 1.5 \\
\hline Feb. & 44.95 & 1.55 & 55.1 & 1.9 \\
\hline Mar. & 72.13 & 2.40 & 89.9 & 2.9 \\
\hline Apr. & 108.0 & 3.60 & 135.0 & 4.5 \\
\hline May. & 132.6 & 4.42 & 162.0 & 5.4 \\
\hline Jun. & 71.25 & 2.38 & - & - \\
\hline Total mm & 573.28 & - & 680.90 & - \\
\hline
\end{tabular}

The amounts of applied irrigation water (AIW) by drip irrigation system to the fodder beet according to the irrigation treatments for the two growing seasons are presented in Table (3) according to Doerenbos and Kassam (1979) and James (1998).

Results indicated that the amount of applied water values were 5305.07, 4243.78 and 3183.04 $\mathrm{m}^{3} /$ ha. In the first season, while it were 5514.79 , 4412.23 and $3529.59 \mathrm{~m}^{3} / \mathrm{ha}$. In the second season for the irrigation treatments 100,80 and $60 \% \mathrm{ET}_{\mathrm{P}}$, re- spectively. At the beginning of the season the amount of applied water was low and increased after this due to increasing the vegetative growth of fodder beet that covered the soil surface. The highest values of water applied under irrigation treatment $\left(100 \% \mathrm{ET}_{\mathrm{P}}\right)$ due to evaporation from the soil surface increased at high moisture content as well as supplying plants with sufficient moisture led to increase green cover which increase transpiration. 
Table (3) Amount of applied water (mm) as affected by irrigation regimes during 2013/14 and 2014/15 growing seasons.

\begin{tabular}{|l|l|l|l|l|l|l|}
\hline \multirow{2}{*}{ Month } & \multicolumn{3}{|c|}{$\mathbf{2 0 1 3 / 1 4}$} & \multicolumn{3}{c|}{ 2014/15 } \\
\cline { 2 - 7 } & $\mathbf{1 0 0 \% \text { Etp }}$ & $\mathbf{8 0 \% \text { Etp }}$ & $\mathbf{6 0 \% \text { Etp }}$ & \multicolumn{1}{|c|}{ 100\%Etp } & 80\%Etp & 60\% Etp \\
\hline Oct. & - & - & - & 46.90 & 37.52 & 22.51 \\
\hline Nov. & 58.48 & 46.78 & 35.09 & 59.36 & 47.49 & 28.49 \\
\hline Dec. & 44.565 & 35.65 & 26.74 & 44.48 & 35.58 & 21.35 \\
\hline Jan. & 37.08 & 29.66 & 22.25 & 36.96 & 29.57 & 17.74 \\
\hline Feb. & 46.08 & 36.86 & 27.65 & 47.92 & 38.34 & 23.0 \\
\hline Mar & 71.28 & 57.02 & 42.77 & 71.68 & 57.34 & 34.4 \\
\hline Apr. & 106.80 & 85.44 & 64.08 & 111.16 & 88.93 & 53.36 \\
\hline May & 131.2 & 104.96 & 78.72 & 133.28 & 106.62 & 63.97 \\
\hline Jun. & 35.24 & 28.19 & 21.14 & - & - & - \\
\hline Total mm & 530 & 424.56 & 318.43 & 551.7 & 441.39 & 353.11 \\
\hline m ${ }^{3} /$ ha & 5305.07 & 4243.78 & 3183.04 & 5514.79 & 4412.23 & 3529.59 \\
\hline
\end{tabular}

Water utilization efficiency $\left(\mathrm{WU}_{\mathrm{t}} \mathrm{E}\right)$ was calculated according to Jensen (1983). To assess and compare of farm profitability of all tested variables the total input, output and investment ratios were calculated.

Statistical analysis data were statistically analyzed according to the technique of analysis of variance (ANOVA) for the strip plots design as described by Steel and Torrie (1980). Least significant difference (L.S.D) method used to test the differences between treatment means at $5 \%$ level of probability as described by Snedecor and Cochran (1980). Meanwhile, the combined analysis of variance was performed for the data of the two seasons after tested the homogeneity of error by Bartlett's test (Steel and Torrie 1980). The processes of the analyses were carried out, using SAS program (SAS 2014).

\section{RESULTS AND DISCUSSION}

\section{Crop Growth Rate (CGR):}

Data in Table (4) and Fig (1) indicated that both soil moisture stress and potassium fertilization had significant effects on CGR at the first period (90-120 DAS) and the second period (120-150 DAS). Maximum values of such trait were obtained from the wet treatment, which was watered with amount of water equals $100 \%$ of potential evapotranspiration (ETp).However, the minimum values were obtained from dry treatment (irrigation with amount of water equals $60 \%$ of potential evapotranspiration (ETp) in the both seasons and combining analysis). These finding may be due to the importance of water to dry matter accumulation or formation of photosynthesiate compounds, (Abdo, Fatma and Anton 2009). Moreover, it was suggested that, at the cellular level drought stress causes shrinkage of cells, cell-membrane injury, and production of free radicals that cause damage to the cellular apparatus, (Terbea et al, 1995 and Sgherri et al,1996).Similar results were obtained by Mary Henen (2011) on sunflower plants.
Regarding the effect of potassium fertilization, adding $171.36 \mathrm{KgK}_{2} \mathrm{O}$ /ha significantly increased CGR at the two period under study in the both seasons and combining analysis. Such finding was attributed to significant regulatory roles of $\mathrm{K}$ in numerous plant physiological processes via, stomatal regulation, photosynthesis, nutrient balance and dry matter accumulation (.Marschner, 2012).

Significant interaction between water treatment and potassium fertilization was expressed for CGR at the second period under this study in both seasons and combining analysis.Plants irrigated with amount of water equals $100 \%$ of $\mathrm{ET}_{\mathrm{p}}$ and received $171.36 \mathrm{Kg}$ $\mathrm{K}_{2} \mathrm{O} /$ ha gives the highest values.

\section{Root length and Diameter $(\mathrm{cm})$}

Data of table (4) and (Fig 2) showed that, water deficit decreased significantly root length of fodder beet plant. Such results can be explained on the bases that under surface drip irrigation system, water in the surface layer was available and roots may absorb water in easy way. On the other hand, Miseha et al. (1992) and, Anton et al (1995) found that water stress increased root length of fodder beet plants under surface irrigation system. The same trend was found for root diameter. Such data revealed that deficiency of soil water, limits root growth and functioning.

Table (4) and (Fig2) showed that increasing potassium fertilization up to $171.36 \mathrm{KgK}_{2} \mathrm{O} / \mathrm{ha}$ increased significantly root length and root diameter in both seasons and combining analysis. Such results may prove the important of potassium for those crops which store carbohydrates like fodder beet plants. Also, Romheld and Kirk (2010) suggested that, increasing root growth by applying K, increases the root surface area under drought conditions, which ultimately enhances the water uptake by plant cells.

There was significant effect due to the interaction between irrigation treatments and potassium fertilization levels on root length in both seasons 
and combining analysis as shown from results in table (4) and (Fig 2). The highest values were obtained from plants irrigated with $100 \%$ and $80 \%$ of $\left.\left(\mathrm{ET}_{\mathrm{p}}\right)\right)$ and received $171.36 \mathrm{KgK}_{2} \mathrm{O} /$ ha with in- significant difference. While root diameter did not affect by the interaction between irrigation treatments and potassium fertilization leaves

Table (4): Effect of irrigation regimes and potassium levels on CGR (g/plant/week) at (90-120 DAS) and (120-150DAS), Root length $(\mathrm{cm})$ and Root diameter $(\mathrm{cm})$ in 2013/14 and 2014/15 seasons.

\begin{tabular}{|c|c|c|c|c|c|c|c|c|c|}
\hline \multicolumn{2}{|c|}{ Treatments } & \multicolumn{2}{|c|}{$\begin{array}{c}\text { CGR } \\
\text { g/plant/week) } \\
(90-120 \text { DAS })\end{array}$} & \multicolumn{2}{|c|}{$\begin{array}{c}\text { CGR } \\
\text { g/plant/week) } \\
(120-150 \text { DAS }) \\
\end{array}$} & \multicolumn{2}{|c|}{ Root length $(\mathrm{cm})$} & \multicolumn{2}{|c|}{ Root diameter $(\mathrm{cm})$} \\
\hline $\begin{array}{l}\text { Irrigation } \\
\text { regimes }\end{array}$ & $\begin{array}{c}\text { Potassium } \\
\text { levels Kg/ha }\end{array}$ & $2013 / 14$ & 2014/15 & $2013 / 14$ & $2014 / 15$ & $2013 / 14$ & $2014 / 15$ & $2013 / 14$ & $2014 / 15$ \\
\hline \multirow{5}{*}{$\mathrm{I}_{1}$} & 0 & 4.81 & 5.01 & 11.26 & 11.98 & 35.97 & 39.60 & 13.20 & 14.33 \\
\hline & 57.12 & 5.60 & 5.96 & 13.41 & 14.88 & 37.77 & 44.17 & 14.50 & 15.00 \\
\hline & 114.24 & 7.39 & 8.05 & 16.40 & 16.90 & 39.40 & 44.40 & 14.83 & 15.00 \\
\hline & 171.36 & 9.32 & 9.74 & 20.33 & 22.60 & 45.13 & 49.13 & 15.50 & 16.16 \\
\hline & Mean & 6.78 & 7.19 & 15.35 & 16.59 & 39.57 & 44.32 & 14.51 & 15.25 \\
\hline \multirow{5}{*}{$\mathrm{I}_{2}$} & 0 & 4.36 & 4.80 & 10.90 & 11.02 & 27.17 & 35.67 & 11.66 & 11.00 \\
\hline & 57.12 & 5.41 & 5.81 & 12.88 & 14.10 & 35.20 & 40.37 & 13.00 & 12.00 \\
\hline & 114.24 & 7.26 & 7.88 & 15.76 & 15.88 & 40.53 & 45.60 & 13.10 & 14.66 \\
\hline & 171.36 & 9.21 & 9.61 & 19.63 & 20.40 & 43.40 & 48.23 & 13.83 & 14.67 \\
\hline & Mean & 6.56 & 7.02 & 14.79 & 15.35 & 36.57 & 42.57 & 12.87 & 13.08 \\
\hline \multirow{5}{*}{$\mathrm{I}_{3}$} & 0 & 3.91 & 4.12 & 9.88 & 10.33 & 20.10 & 36.00 & 9.66 & 10.00 \\
\hline & 57.12 & 5.06 & 5.20 & 10.41 & 12.26 & 23.97 & 39.97 & 10.16 & 10.83 \\
\hline & 114.24 & 7.07 & 7.60 & 14.60 & 15.20 & 26.80 & 41.57 & 10.00 & 11.50 \\
\hline & 171.36 & 8.96 & 9.31 & 18.67 & 19.33 & 28.23 & 42.37 & 11.83 & 12.83 \\
\hline & Mean & 6.25 & 6.55 & 13.39 & 14.30 & 24.77 & 39.98 & 10.41 & 11.21 \\
\hline \multicolumn{2}{|c|}{ Potassium levels $0 \mathrm{Kg} / \mathrm{ha}$} & 4.36 & 4.64 & 10.68 & 11.11 & 27.74 & 37.09 & 11.50 & 11.77 \\
\hline \multicolumn{2}{|c|}{ Potassium levels $57.12 \mathrm{Kg} / \mathrm{ha}$} & 5.35 & 5.65 & 12.23 & 13.74 & 32.31 & 41.50 & 12.55 & 12.61 \\
\hline \multicolumn{2}{|c|}{$\begin{array}{l}\text { Potassium levels } 114.24 \\
\mathrm{Kg} / \mathrm{ha}\end{array}$} & 7.24 & 7.84 & 15.58 & 16.03 & 35.58 & 43.86 & 12.64 & 13.72 \\
\hline \multicolumn{2}{|c|}{$\begin{array}{l}\text { Potassium levels } \\
171.36 \mathrm{Kg} / \mathrm{ha}\end{array}$} & 9.16 & 9.55 & 19.54 & 20.77 & 38.92 & 46.57 & 13.72 & 14.55 \\
\hline \multicolumn{2}{|c|}{$\operatorname{LSD}_{(0.05)} \mathrm{I}$} & 0.15 & 0.11 & 0.33 & 0.247 & 2.13 & 2.86 & 1.63 & 1.32 \\
\hline \multicolumn{2}{|l|}{$\operatorname{LSD}_{(0.05)} \mathrm{K}$} & 0.12 & 0.09 & 0.30 & 0.219 & 2.01 & 2.57 & 1.51 & 1.26 \\
\hline \multicolumn{2}{|l|}{$\operatorname{LSD}_{(0.05)} \mathrm{I} * \mathrm{~K}$} & NS & NS & 0.50 & 0.320 & 3.05 & 3.99 & NS & NS \\
\hline
\end{tabular}

Irrigation treatment: I1, I2, \& I3 = 100, 80, \&60\% potential evapotranspiration (ETp) class A pan.

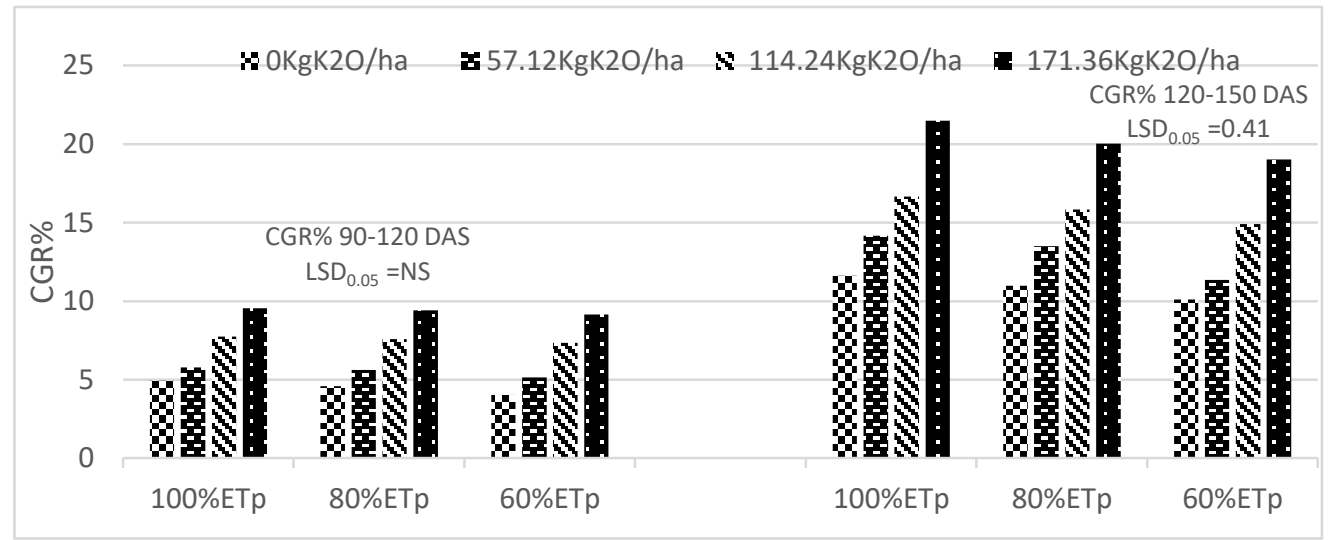

Fig (1): Effect of irrigation regimes and potassium levels on CGR (g/plant/week) (90-120 DAS) and (120-150 DAS) in combined data 


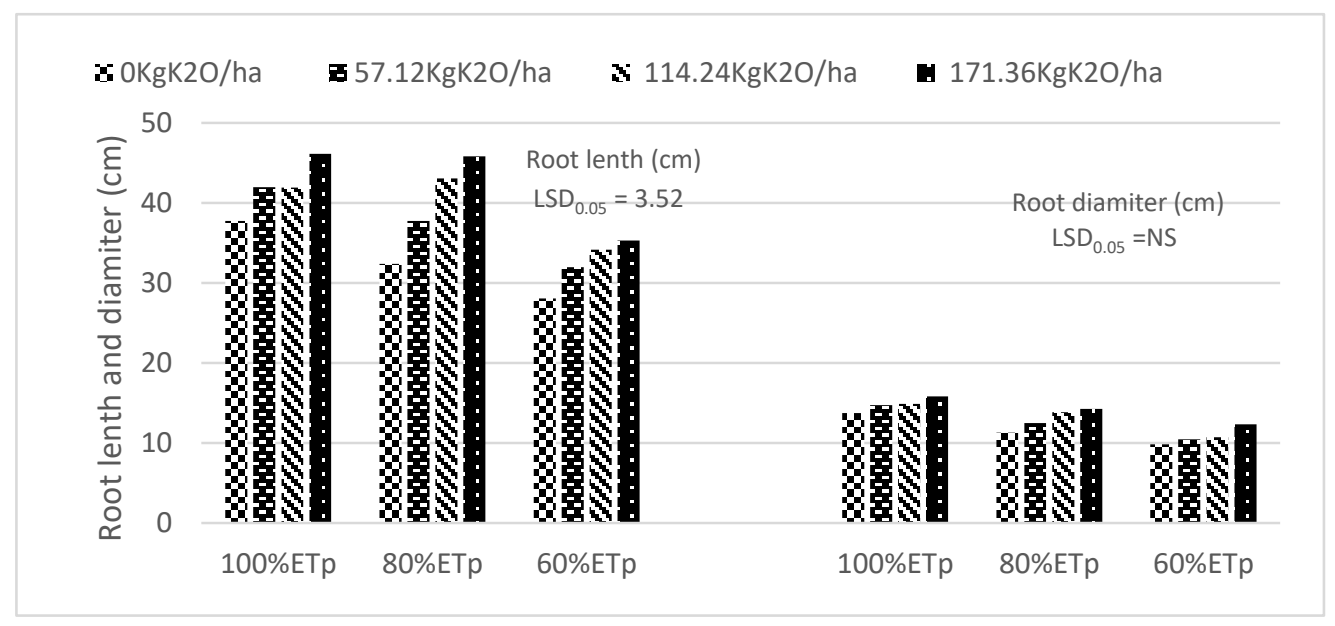

Fig (2): Effect of irrigation regimes and potassium levels on Root length and Root diameter in combined data

\section{Root and Leaves Fresh Weight (kg/plant):}

Data in table (5) and (Fig 3) showed that, root and leaves fresh weight $(\mathrm{Kg} / \mathrm{plant})$ decreased with increasing soil water moisture stress $\left(\mathrm{I}_{2}, \mathrm{I}_{3}\right)$ in both seasons and combining analysis. Foyer and Noctor (2000) stated that drought stress inhibited photosynthetic activity in tissues due to the in balance between light capture and its utilization.

Table (5): Effect of irrigation regimes and potassium levels on Root and Leaves fresh weight (Kg/plant) and Root and Leaves dry weight ( $\mathrm{g} / \mathrm{plant}$ ) in 2013/14 and 2014/15 seasons.

\begin{tabular}{|c|c|c|c|c|c|c|c|c|c|}
\hline \multicolumn{2}{|c|}{ Treatment } & \multicolumn{2}{|c|}{$\begin{array}{l}\text { Root fresh weight } \\
\text { (Kg/plant) }\end{array}$} & \multicolumn{2}{|c|}{$\begin{array}{c}\text { Leaves fresh } \\
\text { weight }(\mathrm{Kg} / \text { plant })\end{array}$} & \multicolumn{2}{|c|}{$\begin{array}{l}\text { Root dry weigh } \\
\text { ( g/plant) }\end{array}$} & \multicolumn{2}{|c|}{$\begin{array}{l}\text { weight Leaves } \\
\text { dry (g/plant) }\end{array}$} \\
\hline $\begin{array}{l}\text { Irrigation } \\
\text { regimes }\end{array}$ & $\begin{array}{c}\text { Potassium } \\
\text { levels Kg/ha }\end{array}$ & $2013 / 14$ & $2014 / 15$ & $2013 / 14$ & $2014 / 15$ & $2013 / 14$ & $2014 / 15$ & $2013 / 14$ & $2014 / 15$ \\
\hline \multirow{5}{*}{$\mathrm{I}_{1}$} & 0 & 1.340 & 1.346 & 0.479 & 0.470 & 157.41 & 159.94 & 64.21 & 62.90 \\
\hline & 57.12 & 1.398 & 1.434 & 0.486 & 0.490 & 190.60 & 195.80 & 66.02 & 66.40 \\
\hline & 114.24 & 1.630 & 1.615 & 0.491 & 0.495 & 290.67 & 286.41 & 68.60 & 71.18 \\
\hline & 171.36 & 1.696 & 1.742 & 0.510 & 0.512 & 304.2 & 315.22 & 72.15 & 74.90 \\
\hline & Mean & 1.516 & 1.534 & 0.492 & 0.492 & 235.72 & 239.34 & 67.74 & 68.83 \\
\hline \multirow{5}{*}{$\mathrm{I}_{2}$} & 0 & 1.243 & 1.342 & 0.419 & 0.423 & 151.32 & 154.22 & 61.33 & 60.88 \\
\hline & 57.12 & 1.309 & 1.340 & 0.440 & 0.456 & 183.40 & 189.14 & 63.72 & 66.40 \\
\hline & 114.24 & 1.524 & 1.566 & 0.446 & 0.469 & 269.22 & 271.68 & 64.90 & 69.20 \\
\hline & 171.36 & 1.526 & 1.602 & $0 . .492$ & 0.494 & 281.67 & 298.40 & 71.81 & 70.33 \\
\hline & Mean & 1.401 & 1.465 & 0.449 & 0.461 & 221.40 & 228.36 & 65.44 & 66.70 \\
\hline \multirow{5}{*}{$\mathrm{I}_{3}$} & 0 & 1.130 & 1.154 & 0.416 & 0.383 & 148.67 & 144.32 & 58.20 & 57.66 \\
\hline & 57.12 & 1.286 & 1.356 & 0.429 & 0.417 & 170.44 & 222.6 & 60.18 & 64.20 \\
\hline & 114.24 & 1.373 & 1.447 & 0.431 & 0.453 & 250.11 & 262.41 & 63.15 & 67.14 \\
\hline & 171.36 & 1.476 & 1.525 & 0.462 & 0.472 & 266.14 & 276.11 & 66.18 & 68.20 \\
\hline & Mean & 1.316 & 1.370 & 0.435 & 0.431 & 208.84 & 241.36 & 61.92 & 64.30 \\
\hline \multicolumn{2}{|c|}{ Potassium levels $0 \mathrm{Kg} / \mathrm{ha}$} & $1 . .237$ & 1.280 & 0.438 & 0.425 & 182.13 & 193.16 & 61.24 & 60.48 \\
\hline \multicolumn{2}{|c|}{$\begin{array}{l}\text { Potassium levels } 57.12 \\
\mathrm{Kg} / \mathrm{ha}\end{array}$} & 1.331 & 1.377 & 0.452 & 0.454 & 211.48 & 219.51 & 63.30 & 66.66 \\
\hline \multicolumn{2}{|c|}{$\begin{array}{l}\text { Potassium levels } 114.24 \\
\mathrm{Kg} / \mathrm{ha}\end{array}$} & 1.531 & 1.543 & 0.456 & 0.472 & 270.00 & 273.50 & 65.55 & 69.17 \\
\hline \multicolumn{2}{|c|}{$\begin{array}{l}\text { Potassium levels } 171.36 \\
\mathrm{Kg} / \mathrm{ha}\end{array}$} & 1.544 & 1.623 & 0.488 & 0.493 & 284.00 & 296.57 & 70.04 & 71.14 \\
\hline \multicolumn{2}{|l|}{$\operatorname{LSD}_{(0.05)} \mathrm{I}$} & 0.081 & 0.067 & 0.031 & 0.022 & 6.164 & 6.421 & 2.021 & 1.249 \\
\hline \multicolumn{2}{|c|}{$\operatorname{LSD}_{(0.05)} \mathrm{K}$} & 0.069 & 0.082 & 0.013 & 0.014 & 4.811 & 5.417 & 1.179 & 1.201 \\
\hline \multicolumn{2}{|c|}{$\operatorname{LSD}_{(0.05)} \mathrm{I} * \mathrm{~K}$} & 0.148 & 0.137 & 0.014 & 0.016 & 5.963 & 7.424 & 2.211 & 1.759 \\
\hline
\end{tabular}

Irrigation treatment: $\mathrm{I}_{1}, \mathrm{I}_{2}, \& \mathrm{I}_{3}=100,80, \& 60 \%$ potential evapotranspiration (ETp) class A pan. 


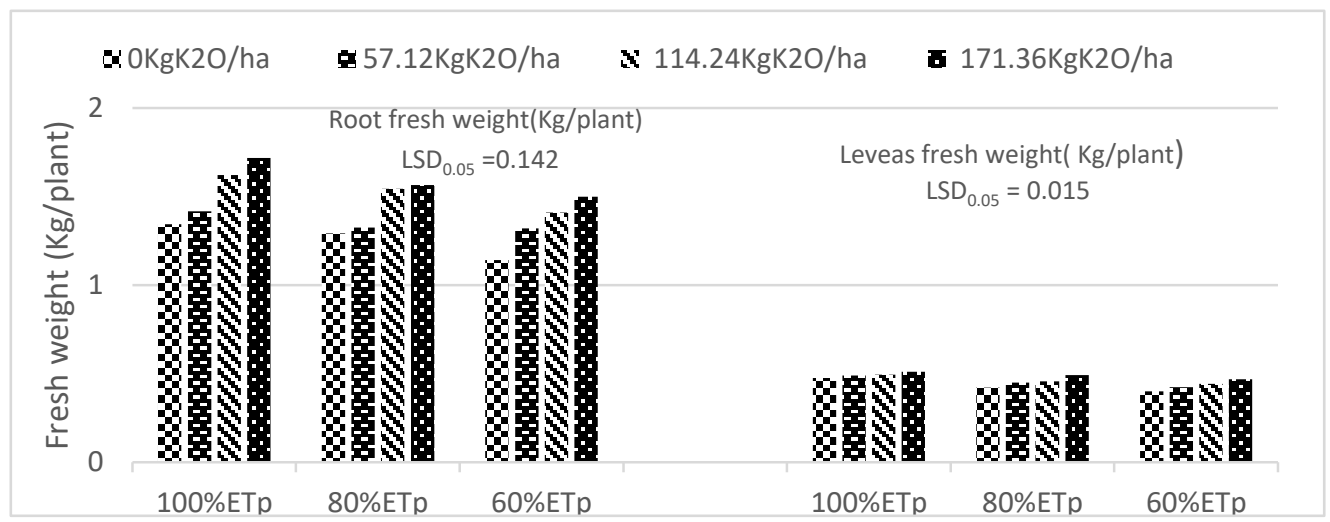

Fig (3): Effect of irrigation regimes and potassium on Root and leaves fresh weight in combined data

As for the effect of potassium fertilization, results indicated that the maximum leaves fresh weight (Kg/plant) achieved when plants received 171.36 $\mathrm{KgK}_{2} \mathrm{O} / \mathrm{ha}$ in both seasons and combining analysis. While the maximum root fresh weight (Kg/plant) were achieved when plant received $171.36 \mathrm{KgK}_{2} \mathrm{O} / \mathrm{ha}$ followed by $114.24 \mathrm{KgK}_{2} \mathrm{O} / \mathrm{ha}$ with insignificant differences between such two treatments. In this concern, Tang et al (2015) pointed that $\mathrm{K}$ is indispensable mineral constituent, intrinsically playing a key role in plant growth and development processes.

From Table (5) and (Fig 3) it was noticed that there was significant interaction between irrigation treatments and potassium fertilization on leaves and root fresh weight ( $\mathrm{Kg} / \mathrm{plant})$ in both seasons and combining analysis. The maximum values were achieved from plants irrigated with water equal $100 \%$ of $\mathrm{ET}_{\mathrm{p}}$ and received $171.36 \mathrm{Kg} \mathrm{K}_{2} \mathrm{O} / \mathrm{ha}$ for leaves fresh weight (Kg/plant) in both seasons and combining analysis. While Plants irrigated with water equal $100 \%$ of $\mathrm{ET}_{\mathrm{p}}$ and received 114.24 and $171.36 \mathrm{KgK}_{2} \mathrm{O} /$ ha gave the highest values for root fresh weight (kg/plant) in both seasons and combining analysis with insignificant difference.

\section{Root and Leaves dry Weight (g/plant):}

Results of Table (5) and Fig (4) showed that, decreasing soil water moisture decreased significantly root and leaves dry weight (g/plant) in both seasons and combining analysis. In this concern, the reduction in vegetative biomass caused by drought result in lower plant surface are which reduces the radiation use efficiency and photosynthetic activities [Stockel and kiniry (1990) and Badr et al (2004)]. Also, Kramer (1969) conducted that water stress can reduce photosynthesis by reducing leaf area, Closure of stomata and reduction in activity of the dehydrated protoplasmic machinery. These results are in line with Mary Henen (2011) in sunflower plants and Kassab et al (2012) in Fodder beet plants.
Concerning to potassium fertilization, data presented in table (5) and Fig (4) clearly show that the application of $171.36 \mathrm{KgK}_{2} \mathrm{O}$ /ha increased significantly leaves and root dry weight ( $\mathrm{g} / \mathrm{plant})$ in both seasons and combining analysis. These results may be due to that potassium takes part in protein synthesis, carbohydrate metabolism, and enzyme activation, Wang et al (2013). In this concern, Egilla et al (2001) suggested that, a sufficient supply of K can improve the plant dry weight better than a lower concentration of $\mathrm{K}$ can in soil under drought conditions.

Data listed in table (5) and Fig (4) show that there was significant interaction between irrigation regimes and potassium fertilization on leaves and root dry weight (g/plant) in both seasons and combining analysis. The maximum values were obtained from plants watered by $100\left(\mathrm{ET}_{\mathrm{p}}\right)$ and received $171.36 \mathrm{KgK}_{2} \mathrm{O} / \mathrm{ha}$, for root dry weight in the two seasons and combining analysis and for leaves dry weight in the second season and combining analysis. While maximum leaves dry weight value in the first season was achieved from plant watered by $100 \%, 80 \%$ from $\mathrm{ET}_{\mathrm{p}}$ and received $171.36 \mathrm{KgK}_{2} \mathrm{O} / \mathrm{ha}$ with insignificant difference.

\section{Yield and yield component:}

Root and foliage weight as well as total weight (ton/ha) are presented in Table (6). Results indicated that root yield and total weight of yield (ton/ha) significantly affected by irrigation treatment in both seasons and combining analysis. The maximum values were achieved when plants irrigated with amount of water equal $100 \%$ of $\left(\mathrm{ET}_{\mathrm{p}}\right)$ (55.195 and 67.25 ton/ha) and (59.934 and 73.00 ton/ha) in both seasons respectively followed by irrigation treatment with amount of water equal $80 \%$ of $\left(\mathrm{ET}_{\mathrm{p}}\right)$ with insignificant differences between such two treatments for root weight and total weight in both seasons and combining analy- 
sis. While the lowest values were obtained from plants irrigated with amount of water equal $60 \%$ of $\left(\mathrm{ET}_{\mathrm{p}}\right)$ (36.445 and 44.590) and (41.936 and 52.31 ton/ha) in both seasons and combining analysis. On the other hand, foliage weight (ton/ha) did not affected by water stress. In this concern, Human et al (1990)and Hall et al (1990) pointed out response to water stress conditions decrease photosynthesis and respiration, and as a result overall production of the crop is decreased. The results coincided with those obtained by kassab et al (2012) and sakr et al (2014) in fodder beet plants

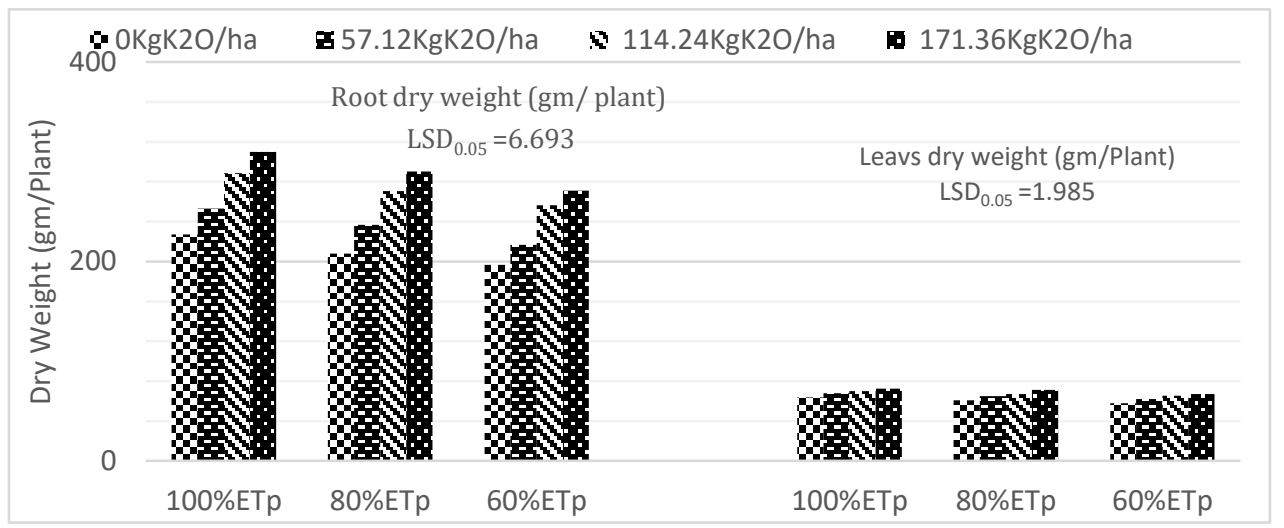

Fig (4): Effect of irrigation regimes and potassium levels on Root and Leaves dry weight in combined data.

Table (6): Effect of irrigation regimes and potassium levels on Root yield ton/ha, Foliage yield ton/ha and total Yield ton/ha in 2013/14 and 2014/15 seasons

\begin{tabular}{|c|c|c|c|c|c|c|c|}
\hline \multicolumn{2}{|c|}{ Treatment } & \multicolumn{2}{|c|}{ Root yield ton/ha } & \multicolumn{2}{|c|}{ Foliage yield ton/ha } & \multicolumn{2}{|c|}{ yield ton/ha Total } \\
\hline $\begin{array}{l}\text { Irrigation } \\
\text { regimes }\end{array}$ & $\begin{array}{c}\text { Potassium levels } \\
\text { Kg/ha }\end{array}$ & 2013/14 & $2014 / 15$ & $2013 / 14$ & $2014 / 15$ & 2013/14 & $2014 / 15$ \\
\hline \multirow{5}{*}{$\mathrm{I}_{1}$} & 0 & 50.847 & 56.280 & 10.323 & 11.442 & 61.170 & 67.772 \\
\hline & 57.12 & 53.078 & 58.029 & 11.252 & 12.301 & 64.330 & 70.330 \\
\hline & 114.24 & 55.641 & 60.151 & 12.189 & 13.179 & 67.830 & 73.330 \\
\hline & 171.36 & 61.214 & 65.277 & 14.456 & 15.383 & 75.670 & 80.660 \\
\hline & Mean & 55.195 & 59.934 & 12.055 & 13.076 & 67.250 & 73.002 \\
\hline \multirow{5}{*}{$\mathrm{I}_{2}$} & 0 & 43.665 & 49.004 & 9.495 & 10.656 & 53.160 & 59.660 \\
\hline & 57.12 & 50.785 & 54.061 & 11.215 & 11.939 & 62.000 & 66.000 \\
\hline & 114.24 & 52.378 & 56.732 & 13.782 & 14.928 & 66.160 & 71.660 \\
\hline & 171.36 & 63.028 & 63.840 & 11.972 & 16.160 & 75.000 & 80.000 \\
\hline & Mean & 52.464 & 59.909 & 11.616 & 13.421 & 64.080 & 69.330 \\
\hline \multirow{5}{*}{$\mathrm{I}_{3}$} & 0 & 32.730 & 38.321 & 5.822 & 7.423 & 38.552 & 45.744 \\
\hline & 57.12 & 37.411 & 39.060 & 7.820 & 9.822 & 45.231 & 48.882 \\
\hline & 114.24 & 37.110 & 44.133 & 9.201 & 11.141 & 46.311 & 55.274 \\
\hline & 171.36 & 38.530 & 46.192 & 11.164 & 13.142 & 49.694 & 59.334 \\
\hline & Mean & 36.445 & 41.936 & 8.507 & 10.388 & 44.598 & 52.324 \\
\hline \multicolumn{2}{|c|}{ Potassium levels $0 \mathrm{Kg} / \mathrm{ha}$} & 42.414 & 47.868 & 8.546 & 9.839 & 50.960 & 57.686 \\
\hline \multicolumn{2}{|c|}{ Potassium levels $57.12 \mathrm{Kg} / \mathrm{ha}$} & 47.091 & 50.383 & 10.095 & 11.353 & 57.186 & 61.710 \\
\hline \multicolumn{2}{|c|}{ Potassium levels $114.24 \mathrm{Kg} / \mathrm{ha}$} & 48.376 & 53.671 & 11.723 & 13.082 & 60.100 & 66.753 \\
\hline \multicolumn{2}{|c|}{ Potassium levels $171.36 \mathrm{Kg} / \mathrm{ha}$} & 54.257 & 58.435 & 12.529 & 14.894 & 66.787 & 73.33 \\
\hline \multicolumn{2}{|c|}{$\operatorname{LSD}_{(0.05)} \mathrm{I}$} & 5.543 & 6.764 & NS & NS & 6.361 & 6.746 \\
\hline \multicolumn{2}{|l|}{$\operatorname{LSD}_{(0.05)} \mathrm{K}$} & 3.022 & 3.712 & 1.582 & 1.373 & 4.031 & 3.145 \\
\hline \multicolumn{2}{|l|}{$\operatorname{LSD}_{(0.05)} \mathrm{I} * \mathrm{~K}$} & 5.681 & 4.881 & NS & NS & 5.292 & 5.278 \\
\hline
\end{tabular}

Irrigation treatment: $\mathrm{I}_{1}, \mathrm{I}_{2}, \& \mathrm{I}_{3}=100,80, \& 60 \%$ potential evapotranspiration (ETp) class A pan. 


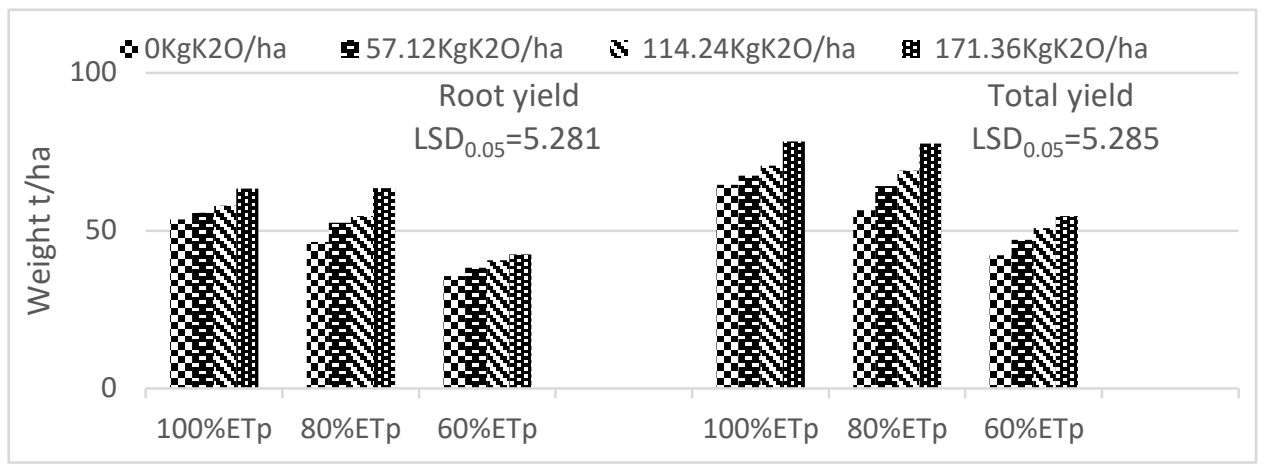

\section{Fig (5) Effect of irrigation regime and potassium levels on root and foliage and total yield (ton/ha) in combined data}

As for potassium fertilization, data in Table (6) exhibited that potassium levels had significant effect on yield production of fodder beet plants via. root and foliage weight as well as total weight of yield (ton/ha). Increasing potassium levels up to $171.36 \mathrm{Kg} \mathrm{K}_{2} \mathrm{O} / \mathrm{ha}$ produced the highest values of these traits in both seasons and combining analysis. The improvements due to increasing potassium fertilization levels may be ascribed to the vital regulatory functions of potassium in photosynthesis process, photosynthesis translocation, improving the osmotic adjustment as well as activation of plant enzymes and antioxidant defense system, (sakr et al 2014 and Hasanozzarman et al 2018). These results are in line with those stated by Kassab et al (2012) and Mary- Nashed et al (2019).

There was significant effect due to the interaction between irrigation treatments and potassium levels on root and total weight of yield (ton/ha) in both seasons and combining analysis in table (6) and (Fig 5). The highest values were obtained from plants irrigated with amount of water equal $100 \%$ of $\left(\mathrm{ET}_{\mathrm{p}}\right)$ and received $171.36 \mathrm{Kg} \mathrm{K} \mathrm{O} /$ ha followed by plants irrigated with $80 \%$ of $\mathrm{ET}_{\mathrm{p}}$ and received 171.36 Kg K $2 \mathrm{O} /$ ha with insignificant differences in both seasons and combining data

\section{Total Chlorophyll of leaves:}

Data in table (7) showed that total chlorophyll were significantly increased when fodder beet plants watered with wet treatment (amount of water equal $100 \%$ from (ETp)), compared to medium or dry treatments, in both seasons and combining analysis. While, dry treatment scored the least value of such trait. That trend, might be due to an important role for pigments formation in leaves. Similar results were obtained by Saad EL-Deen (2006) in sesame plants. The effect of potassium fertilization indicated that adding 171.36 $\mathrm{KgK}_{2} \mathrm{O} /$ ha significantly increased total chlorophyll of leaves in both seasons and combining analysis. The significant increase of chlorophyll content as a result of potassium application could be due to function and performance of many plant enzymes especially which involved in leaf pigments formation (Hawksford et al, 2012). Similar results were obtained by Mary- Nashed et al (2019).
There was no significant effect between water stress and potassium fertilization on total chlorophyll of leaves in both season and combining analysis

\section{Yield Quality:}

Forage quality i.e.; potassium (K \%), total soluble solids (TSS \%), crude protein (CP \%), digestible crude protein (DCP \%), crude fiber (CF \%) and total digestible nutrients (TDN \%) significantly affected by water stress in both seasons and combining analysis. (Tables 7 and 8) and (Fig 6).Increasing soil moisture stress up to $60 \%$ of $\mathrm{ET}_{\mathrm{p}}$ significantly decreased $\%$, $\mathrm{CP} \%, \mathrm{CF} \%$ and $\mathrm{DCP} \%$ in the both seasons and combining data. While, TDN\% and TSS\% were increased by increasing soil moisture stress in both seasons and combining data. This effect of water stress may be due to the reduction in activities vegetative biomass, photosynthetic activities and dry matter accumulation which lead to the decrease of crud protein and fiber. Similar results were obtained by Sakr et al (2014).

With regard to potassium levels, data indicated that there was significant effect on (K \%), (CP \%), (DCP \%), (CF \%) and (TDN \%) due to potassium fertilization level in both seasons and combining analysis except (TSS \%). The highest percentage of $\mathrm{CP} \%$ in the both seasons and combining data and $\mathrm{CF} \%$ in the first seasons and combining data were achieved by adding114.24 and $171.36 \mathrm{KgK}_{2} \mathrm{O} / \mathrm{ha}$ with insignificant difference. While adding 171.36 $\mathrm{KgK}_{2} \mathrm{O} /$ ha gave the maximum $\mathrm{K} \%$ and $\mathrm{DCP} \%$ in the both seasons and combining analysis and $\mathrm{CF} \%$ in the second season. On the other hand, the maximum TDN\% were obtained from the treatment 0 $\mathrm{KgK}_{2} \mathrm{O} / \mathrm{ha}$ in the both seasons and combining analysis. These results might due to the vital role of potassium in improving photosynthetic activity, enhancing $\mathrm{N}$ absorption, $\mathrm{N}$ metabolism, and protein synthesis. (Wang et al, 2013). In addition potassium fertilizers as a soil dressing improve physical, chemical and biological conditions in soil, which increase the metabolic activity of $\mathrm{K}$ these by improving plant growth, (Tejada et al, 2006). 
Table (7): Effect of irrigation regimes and potassium levels on TSS\%, K\% and Chlorophyll in 2013/14 and 2014/15 seasons

\begin{tabular}{|c|c|c|c|c|c|c|c|}
\hline \multicolumn{2}{|c|}{ Treatment } & \multicolumn{2}{|c|}{ TSS $\%$} & \multicolumn{2}{|c|}{$\mathrm{K} \%$} & \multicolumn{2}{|c|}{ Chlorophyll mg/m² } \\
\hline $\begin{array}{l}\text { Irrigation } \\
\text { regimes }\end{array}$ & $\begin{array}{c}\text { Potassium levels } \\
\mathrm{Kg} / \mathrm{ha}\end{array}$ & 2013/14 & $2014 / 15$ & $2013 / 14$ & $2014 / 15$ & $2013 / 14$ & $2014 / 15$ \\
\hline \multirow{5}{*}{-0} & 0 & 9.24 & 8.62 & 0.411 & 0.458 & 621.26 & 640.8 \\
\hline & 57.12 & 10.11 & 10.33 & 0.436 & 0.490 & 707.2 & 721.90 \\
\hline & 114.24 & 12.03 & 12.34 & 0.495 & 0.509 & 904.5 & 930.1 \\
\hline & 171.36 & 13.23 & 13.59 & 0.524 & 0.566 & 1156.4 & 1201.5 \\
\hline & Mean & 10.65 & 11.22 & 0.467 & 0.506 & 847.34 & 873.57 \\
\hline \multirow{5}{*}{$\mathrm{I}_{2}$} & 0 & 10.48 & 10.66 & 0.341 & 0.383 & 611.9 & 629.8 \\
\hline & 57.12 & 11.44 & 12.30 & 0.426 & 0.456 & 690.4 & 701.4 \\
\hline & 114.24 & 12.79 & 12.88 & 0.453 & 0.480 & 882.6 & 904.3 \\
\hline & 171.36 & 13.05 & 14.11 & 0.510 & 0.560 & 1138.2 & 1178.2 \\
\hline & Mean & 11.80 & 12.48 & 0.433 & 0.474 & 830.77 & 853.42 \\
\hline \multirow{5}{*}{$\mathrm{I}_{3}$} & 0 & 11.21 & 11.14 & 0.306 & 0.333 & 601.3 & 614.8 \\
\hline & 57.12 & 12.29 & 12.67 & 0.327 & 0.358 & 681.7 & 698.2 \\
\hline & 114.24 & 13.26 & 14.35 & 0.409 & 0.511 & 869.9 & 884.1 \\
\hline & 171.36 & 13.71 & 14.83 & 0.433 & 0.531 & 1118.3 & 1149.6 \\
\hline & Mean & 12.64 & 13.24 & 0.368 & 0.433 & 817.80 & 836.67 \\
\hline \multicolumn{2}{|c|}{ Potassium levels $0 \mathrm{Kg} / \mathrm{ha}$} & 9.64 & 10.14 & 0.352 & 0.391 & 611.48 & 628.46 \\
\hline \multicolumn{2}{|c|}{ Potassium levels $57.12 \mathrm{Kg} / \mathrm{ha}$} & 10.94 & 11.76 & 0.396 & 0.434 & 693.10 & 707.16 \\
\hline \multicolumn{2}{|c|}{ Potassium levels $114.24 \mathrm{Kg} / \mathrm{ha}$} & 12.69 & 13.19 & 0.452 & 0.500 & 885.66 & 906.16 \\
\hline \multicolumn{2}{|c|}{ Potassium levels $171.36 \mathrm{Kg} / \mathrm{ha}$} & 13.33 & 14.17 & 0.489 & 0.552 & 1137.63 & 1176.43 \\
\hline \multicolumn{2}{|c|}{$\operatorname{LSD}_{(0.05)} \mathrm{I}$} & 1.43 & 1.52 & 0.038 & 0.023 & 10.016 & 11.701 \\
\hline \multicolumn{2}{|l|}{$\mathrm{LSD}_{(0.05)} \mathrm{K}$} & NS & NS & 0.031 & 0.024 & 7.544 & 8.128 \\
\hline \multicolumn{2}{|l|}{$\operatorname{LSD}_{(0.05)} \mathrm{I} * \mathrm{~K}$} & NS & $\mathrm{NS}$ & NS & NS & NS & $\mathrm{NS}$ \\
\hline
\end{tabular}

Irrigation regimes $\mathrm{I}_{1}, \mathrm{I}_{2}, \& \mathrm{I}_{3}=100,80, \& 60 \%$ potential evapotranspiration (ETp) class A pan.

Table (8): Effect of irrigation regimes and potassium levels on Crud protein\%, Crud fiber\%, DCP\% and TDN\% in 2013/14 and 2014/15 seasons.

\begin{tabular}{|c|c|c|c|c|c|c|c|c|c|}
\hline \multicolumn{2}{|c|}{ Treatment } & \multicolumn{2}{|c|}{ Crud protein\% } & \multicolumn{2}{|c|}{ Crud fiber \% } & \multicolumn{2}{|c|}{ DCP\% } & \multicolumn{2}{|c|}{ TDN\% } \\
\hline $\begin{array}{l}\text { Irrigation } \\
\text { regimes }\end{array}$ & $\begin{array}{c}\text { Potassium } \\
\text { levels Kg/ha }\end{array}$ & $2013 / 14$ & $2014 / 15$ & $2013 / 14$ & $2014 / 15$ & $2013 / 14$ & $2014 / 15$ & $2013 / 14$ & $2014 / 15$ \\
\hline \multirow{5}{*}{$\mathrm{I}_{1}$} & 0 & 6.35 & 6.83 & 8.23 & 7.77 & 2.41 & 2.86 & 85.13 & 85.65 \\
\hline & 57.12 & 7.22 & 8.11 & 8.64 & 8.59 & 3.22 & 3.70 & 85.02 & 85.32 \\
\hline & 114.24 & 8.81 & 8.69 & 9.01 & 8.79 & 4.70 & 4.59 & 85.17 & 85.32 \\
\hline & 171.36 & 9.23 & 10.23 & 9.12 & 9.32 & 5.09 & 6.02 & 85.19 & 85.30 \\
\hline & Mean & 7.90 & 8.46 & 8.75 & 8.61 & 5.04 & 4.29 & 85.12 & 85.40 \\
\hline \multirow{5}{*}{$\mathrm{I}_{2}$} & 0 & 5.62 & 6.13 & 7.92 & 7.41 & 1.74 & 2.21 & 85.17 & 85.75 \\
\hline & 57.12 & 6.29 & 6.91 & 8.04 & 7.65 & 2.36 & 2.93 & 84.77 & 85.78 \\
\hline & 114.24 & 6.37 & 7.24 & 8.62 & 8.21 & 2.43 & 3.24 & 85.28 & 85.38 \\
\hline & 171.36 & 7.71 & 7.66 & 8.55 & 8.63 & 3.68 & 3.63 & 85.23 & 85.15 \\
\hline & Mean & 6.49 & 6.98 & 8.28 & 7.97 & 2.55 & 3.00 & 85.11 & 85.52 \\
\hline \multirow{5}{*}{$\mathrm{I}_{3}$} & 0 & 5.51 & 5.49 & 6.44 & 5.43 & 1.63 & 1.62 & 86.41 & 87.28 \\
\hline & 57.12 & 5.31 & 5.62 & 7.22 & 5.75 & 1.45 & 1.74 & 85.45 & 87.03 \\
\hline & 114.24 & 6.14 & 5.78 & 7.48 & 6.81 & 2.22 & 1.88 & 85.93 & 86.17 \\
\hline & 171.36 & 6.01 & 6.35 & 7.50 & 6.88 & 2.10 & 2.41 & 85.65 & 86.28 \\
\hline & Mean & 5.74 & 5.81 & 7.16 & 6.21 & 1.85 & 1.91 & 85.86 & 86.69 \\
\hline \multicolumn{2}{|c|}{ Potassium levels $0 \mathrm{Kg} / \mathrm{ha}$} & 5.82 & 6.15 & 7.35 & 6.87 & 1.92 & 2.23 & 85.57 & 86.22 \\
\hline \multicolumn{2}{|c|}{ Potassium levels $57.12 \mathrm{Kg} / \mathrm{ha}$} & 6.27 & 6.88 & 7.90 & 7.33 & 2.34 & 2.79 & 85.08 & 86.04 \\
\hline \multicolumn{2}{|c|}{ Potassium levels $114.24 \mathrm{Kg} / \mathrm{ha}$} & 7.10 & 7.23 & 8.37 & 7.93 & 3.11 & 3.23 & 85.46 & 85.62 \\
\hline \multicolumn{2}{|c|}{ Potassium levels $171.36 \mathrm{Kg} / \mathrm{ha}$} & 7.65 & 8.08 & 8.39 & 8.27 & 3.62 & 4.02 & 85.35 & 85.57 \\
\hline \multicolumn{2}{|c|}{$\operatorname{LSD}_{(0.05)} \mathrm{I}$} & 1.12 & 1.34 & 0.54 & 0.49 & 1.03 & 1.10 & 0.07 & 0.06 \\
\hline \multicolumn{2}{|l|}{$\mathrm{LSD}_{(0.05)} \mathrm{K}$} & 0.64 & 1.04 & 0.27 & 0.18 & 0.44 & 0.58 & 0.05 & 0.05 \\
\hline \multicolumn{2}{|l|}{$\operatorname{LSD}_{(0.05)} I * K$} & 0.44 & 0.89 & 0.24 & 0.13 & 0.43 & 0.48 & 0.04 & 0.03 \\
\hline
\end{tabular}

Irrigation regimes $\mathrm{I}_{1}, \mathrm{I}_{2}, \& \mathrm{I}_{3}=100,80, \& 60 \%$ potential evapotranspiration (ETp) class A pan. 


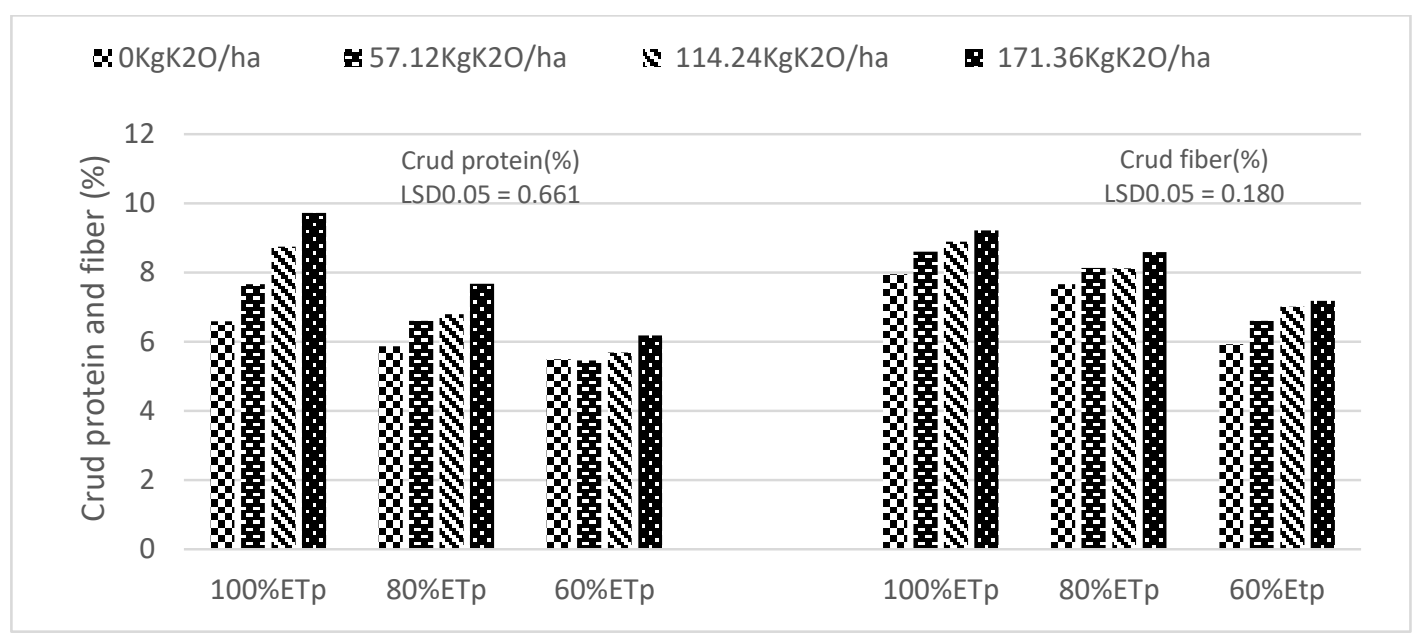

Fig (6) Effect of irrigation regimes and potassium levels on Crud protein \%, Crud fiber\% in combined data.

Concerning the effect of the interaction between irrigation treatments and potassium fertilization levels, there was significant effect on $\mathrm{CP} \%, \mathrm{CF} \%$, DCP\% and TDN\% in both seasons, Table (8) combining analysis (Fig 6). The highest percentage of $\mathrm{CP} \%, \mathrm{CF} \%$ and $\mathrm{DCP} \%$ in the first season were achieved from the wet treatment $\left(100 \%\right.$ from $\left.\mathrm{ET}_{\mathrm{p}}\right)$ in combination with 114.24 and $171.36 \mathrm{KgK}_{2} \mathrm{O} /$ ha with insignificant difference. While the highest $\mathrm{CP} \%$, $\mathrm{CF} \%$ as well as $\mathrm{DCP} \%$ in the second season and combining data were obtained from the wet treatment in combination with $171.36 \mathrm{KgK}_{2} \mathrm{O} / \mathrm{ha}$ as for TDN\%, the highest percentage were obtained from dry treatment $\left(60 \%\right.$ for $\left.\mathrm{ET}_{\mathrm{p}}\right)$ without potassium fertilization $\left(0 \mathrm{KgK}_{2} \mathrm{O} / \mathrm{ha}\right)$.

\section{Relative water content (RWC \%):}

RWC was proposed as good indicator of plant water status (Sinclair and Ludlow, 1985), because RWC through its relation to cell volume, may be more closely reflects the balance between water supply to the leaf and transpiration rate.

Table (9) showed that, RWC significantly affected by the two factors under study. Regarding the effect of water stress on RWC, results indicated that increasing water stress from $100 \%$ ETp to $60 \%$ ETp significantly decreased RWC at 100 DAS in both seasons and combining analysis. Such finding show the water status in plant cells which affected by water stress conditions. In this respect, (Abdo, Fatma and Anton2009) stated that increasing water stress from $20-50 \%$ up to $65-70 \%$ significantly decreased RWC at 70 and 84 DAS in sesame plant.

Concerning the effect of potassium fertilization, RWC significantly increased when fodder beet plants received $171.36 \mathrm{KgK}_{2} \mathrm{O} /$ ha compared with other potassium treatments in both seasons and combining analysis. This might be due to that, $\mathrm{K}$ controls the evapotranspiration $\left(\mathrm{ET}_{\mathrm{p}}\right)$ of water through pores under a water deficit in the soil environment, and it protect the plant from water stress
Thomas and Thomas (2009). In addition to this effect, the osmotic gradient produced due to the accumulation of $\mathrm{K}$ in the root helps to draw water into the root cells Hasanuzzaman et al (2018). Similar results were obtained by (Abdo Fatma and Anton 2009) in sesame plant.

The interaction between soil moisture stress and potassium fertilization on RWC of levels was significant. The highest values were scored from plants irrigated by $100 \%$ from $\mathrm{ET}_{\mathrm{p}}$ and received $171.36 \mathrm{Kg} \mathrm{K}_{2} \mathrm{O} / \mathrm{ha}$ in both seasons, table (9) and combining analysis (Fig7).

\section{Water utilization efficiency $\left(\mathrm{WU}_{\mathrm{t}} \mathrm{E}\right)$ :}

The effect of drip irrigation and potassium treatments on water utilization efficiency as $\mathrm{kg}$ of fodder beet (root + foliage) yield per $\mathrm{m}^{3}$ of applied water during the two growing seasons was presented in Table (9). The results showed that $\mathrm{WU}_{t} \mathrm{E}$ values were $12.67,15.10$ and $14.12 \mathrm{Kg}$ (root + foliage) $/ \mathrm{m}^{3}$ applied water in the first season and it were $13.24 \mathrm{~m}$ 15.71 and $14.82 \mathrm{Kg}$ (root + foliage) $/ \mathrm{m}^{3}$ applied water in the second season for irrigation treatments $\mathrm{I}_{1} \mathrm{I}_{2}$ and $\mathrm{I}_{3}$ respectively. It could be concluded that medium soil moisture level seemed to be more efficient in consuming water compared with eighteen low water deficit (wet treatment) or severe soil moisture stress (dry treatment) in second season and combining analysis . In other words, from the stand point of water conservation, medium treatment seemed to be more economic for saving water and gained a suitable yield. Similar results on soybean was obtained by Amina (2017).

The values of $\mathrm{WU}_{\mathrm{t}} \mathrm{E}$ increased with increasing the rate of potassium fertilization under irrigation treatments in the two growing seasons. In this connection, Pendleton (1965) suggested that fertilization practices which provide adequate nutrition for crop plants play a major role in the efficient use and conservation of water resources. The previous results are in line with those obtained by Welch and Flannery (1985) who concluded that water use 
efficiency of corn plants was increased by raising potassium supply.

The interaction between soil moisture stress and potassium fertilization in Table (9) and Fig (8)

Table (9): Effect of irrigation regimes and potassium levels on Relative water content (RWC \%) and (WUtE) Kg (root + foliage) yield $/ \mathrm{m}^{3}$ applied water in 2013/14 and 2014/15 seasons

\begin{tabular}{|c|c|c|c|c|c|}
\hline \multicolumn{2}{|l|}{ Treatment } & \multicolumn{2}{|l|}{ RWC\% } & \multicolumn{2}{|c|}{$\begin{array}{l}\left(\mathrm{WU}_{\mathrm{t}} \mathrm{E}\right) \mathrm{Kg} \text { (root+ foliage) } / \mathrm{m}^{3} \\
\text { applied water }\end{array}$} \\
\hline $\begin{array}{l}\text { Irrigation re- } \\
\text { gimes }\end{array}$ & $\begin{array}{l}\text { Potassium level } \\
\mathrm{Kg} / \mathrm{ha}\end{array}$ & $2013 / 14$ & $2014 / 15$ & $2013 / 14$ & $2014 / 15$ \\
\hline \multirow{5}{*}{$\mathrm{I}_{1}$} & 0 & 76.41 & 81.40 & 11.529 & 12.268 \\
\hline & 57.12 & 80.41 & 84.71 & 12.130 & 12.752 \\
\hline & 114.24 & 86.52 & 90.60 & 12.785 & 13.298 \\
\hline & 171.36 & 88.24 & 93.35 & 14.265 & 14.626 \\
\hline & Mean & 82.90 & 87.50 & 12.676 & 13.235 \\
\hline \multirow{5}{*}{$\mathrm{I}_{2}$} & 0 & 72.14 & 75.25 & 12.521 & 13.521 \\
\hline & 57.12 & 74.40 & 78.83 & 14.584 & 14.958 \\
\hline & 114.24 & 80.60 & 83.20 & 15.588 & 16.239 \\
\hline & 171.36 & 82.14 & 83.41 & 17.672 & 18.130 \\
\hline & Mean & 77.32 & 80.16 & 15.101 & 15.714 \\
\hline \multirow{5}{*}{$\mathrm{I}_{3}$} & 0 & 60.71 & 63.44 & 12.11 & 12.96 \\
\hline & 57.12 & 61.35 & 64.95 & 14.21 & 13.85 \\
\hline & 114.24 & 67.95 & 72.60 & 14.55 & 15.66 \\
\hline & 171.36 & 68.70 & 72.97 & 15.61 & 16.81 \\
\hline & Mean & 64.67 & 68.48 & 14.12 & 14.82 \\
\hline \multicolumn{2}{|c|}{ Potassium levels $0 \mathrm{Kg} / \mathrm{ha}$} & 69.75 & 73.35 & 12.66 & 13.42 \\
\hline \multicolumn{2}{|c|}{ Potassium levels $57.12 \mathrm{Kg} / \mathrm{ha}$} & 72.06 & 76.16 & 14.24 & 14.66 \\
\hline \multicolumn{2}{|c|}{ Potassium levels $114.24 \mathrm{Kg} / \mathrm{ha}$} & 78.35 & 8.133 & 14.31 & 15.56 \\
\hline \multicolumn{2}{|c|}{ Potassium levels $171.36 \mathrm{Kg} / \mathrm{ha}$} & 79.69 & 83.24 & 15.85 & 16.88 \\
\hline \multicolumn{2}{|c|}{$\operatorname{LSD}_{(0.05)} \mathrm{I}$} & 0.587 & 0.522 & 0.970 & 0.881 \\
\hline \multicolumn{2}{|l|}{$\mathrm{LSD}_{(0.05)} \mathrm{K}$} & 0.409 & 0.484 & 0.901 & 0.832 \\
\hline \multicolumn{2}{|l|}{$\operatorname{LSD}_{(0.05)} I^{*} \mathrm{~K}$} & 0.742 & 0.706 & 1.20 & 1.21 \\
\hline
\end{tabular}

Irrigation regimes: $I_{1}, I_{2}, \& I_{3}=100,80, \& 60 \%$ potential evapotranspiration (ETp) class A pan.

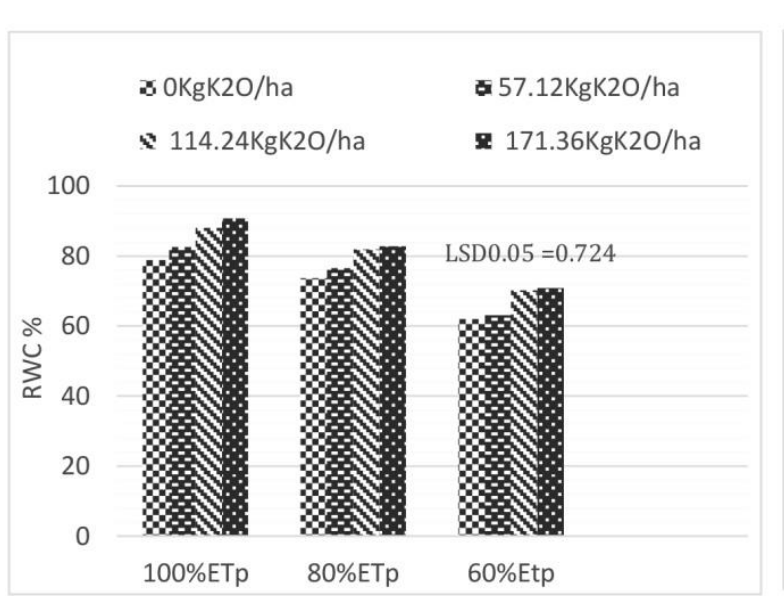

Fig (7) Effect of irrigation regimes and potassium

\footnotetext{
levels on RWC\% in combined data

Profitability assessment:

Data in table (10) showed profitability calcu-
lations for the input values for different treatments

Data in table (10) showed profitability calcu-
lations for the input values for different treatments under study, considering the appraisal of all coats
}

show that the maximum value of $\mathrm{WU}_{\mathrm{t}} \mathrm{E}$ was scored from plants irrigated at $80 \%$ from $\mathrm{ET}_{\mathrm{p}}$ in combination with adding $171.36 \mathrm{KgK}_{2} \mathrm{O} / \mathrm{ha}$ in the both seasons and combining analysis. 
sion will be handled as follows: Data presented in table (12) show that the highest net income, (10586.25 LE/ha) and I.R value, (1.96) as a mean values of two experimental seasons 2013/14 and $2014 / 15$ were attributed to irrigation treatment $\left(I_{2}\right)$ and potassium fertilization $171.36 \mathrm{~kg} / \mathrm{ha}$ level under calcareous soil condition. Also, results revealed that the lowest values $(3267.98 \mathrm{LE} / \mathrm{ha}$ and 1.261 ) of the same parameters were always related to the absence of K-fertilizer under $\left(\mathrm{I}_{3}\right)$ treatment. These results were incorporated with the highest grain yield. Final, from the obtained data it could be concluded that, the investment ratio values were incorporated with the highest net income in the descending order $I_{1}>I_{2}>I_{3}$ and the order of $K_{4}>$ $\mathrm{K}_{3}>\mathrm{K}_{2}>\mathrm{K}_{1}$.

\section{CONCLUSION}

In light of the presented data and under calcareous soil conditions it seems evident that drip irrigation regimes and potassium fertilization levels markedly effected on fodder beet yield and it's components and quality. Data, revealed that the higher total fodder beet yield (78.165 Ton/ha, as an average of two seasons) was obtained under $\mathrm{I}_{1}$ $\left(100 \% \mathrm{ET}_{\mathrm{p}}\right)$ treatment and potassium fertilization levels $171.36 \mathrm{Kg} \mathrm{K} \mathrm{K}_{2} \mathrm{O} / \mathrm{ha}$ followed by irrigation

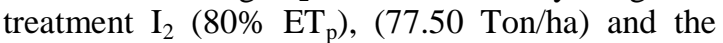
same level of potassium fertilization with insignificant difference between them Also, under the calcareous soil, drip irrigation and experimental conditions, the average amount as a mean values of two growing seasons of applied irrigation water for fodder beet were 5409.93, 4328.01 and 3356.32 $\mathrm{m}^{3} /$ ha for the $I_{1}, I_{2}$ and $I_{3}$ irrigation regimes respectively

On the other hand the maximum value of $\mathrm{WU}_{\mathrm{t}} \mathrm{E}$ (Kg total yield $/ \mathrm{m}^{3}$ applied water) was obtained under $\mathrm{I}_{2}\left(80 \% \mathrm{ET}_{\mathrm{p}}\right)$ and potassium fertilization level $171.36 \mathrm{Kg} \mathrm{K}_{2} \mathrm{O} / \mathrm{ha}$.

In view of profitability assessment, results revealed that the highest net income (10586.2 LE/ha) and I.R (1.960) as an average of two growing seasons were obtained under $\mathrm{I}_{2}$ treatment and 171.36 $\mathrm{Kg} \mathrm{K}_{2} \mathrm{O} /$ ha level.

Accordingly under calcareous soil conditions and drip irrigation system, it is recommended that about $20 \%$ of amounts applied irrigation water could be saved with insignificant decreasing in total fodder beet yield, farm net income and I.R.

Table (10): Input production items and output of the experimental work for fodder bet into the two growing winter seasons of 2013/2014 and 2014/2015

\begin{tabular}{|l|c|c|c|c|}
\hline \multicolumn{1}{|c|}{ Items } & Treatments & $\begin{array}{c}\text { Treatments } \\
\text { unit }\end{array}$ & $\begin{array}{c}\text { Unit price (L.E) } \\
\mathbf{2 0 1 3 / 1 4}\end{array}$ & $\begin{array}{c}\text { Unit price } \\
\text { (L.E)2014/15 }\end{array}$ \\
\hline Inputs & & & & \\
\hline Mineral fertilizers & & & & \\
\hline N & 142.8 & Kg N/ha & 9.55 & 10.75 \\
\hline P2O5 & 71.4 & Kg P2O5/ha & 5.80 & 5.80 \\
\hline K2O & & Kg K2O/ha & & \\
\hline K1 & Zero & & & 11.70 \\
\hline K2 & 57.12 & & 10.42 & 11.70 \\
\hline K3 & 114.24 & & 10.42 & 11.70 \\
\hline K4 & 171.36 & Kg /ha. & 100 & 120 \\
\hline Seeds & 9.5 & Per/ha. & 480 & 530 \\
\hline Land preparation* & & Per/ha. & 1290 & 1420 \\
\hline Labour** & & Per/ha. & 4200 & 4700 \\
\hline Other costs*** & & Ton/ha. & 260 & 280 \\
\hline Outputs Fodder beet yield & & & & \\
\hline
\end{tabular}

* Rent of agricultural machines

** Cultivation, irrigation, fertilization, Thinning,.. etc.

*** Land rent, transportation of seeds, fertilizers,.. etc. Irrigation and drainage systems conservation, . etc. 


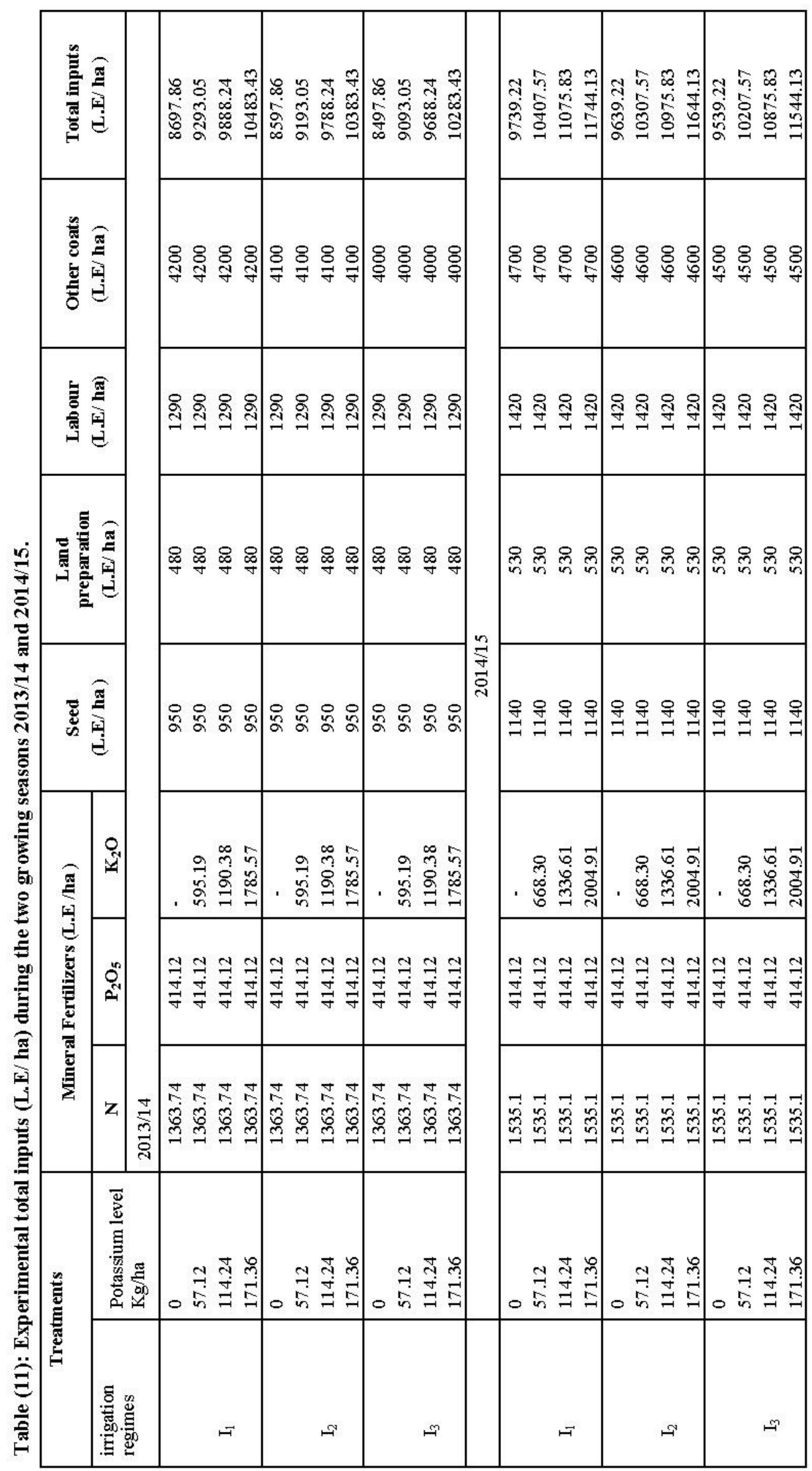




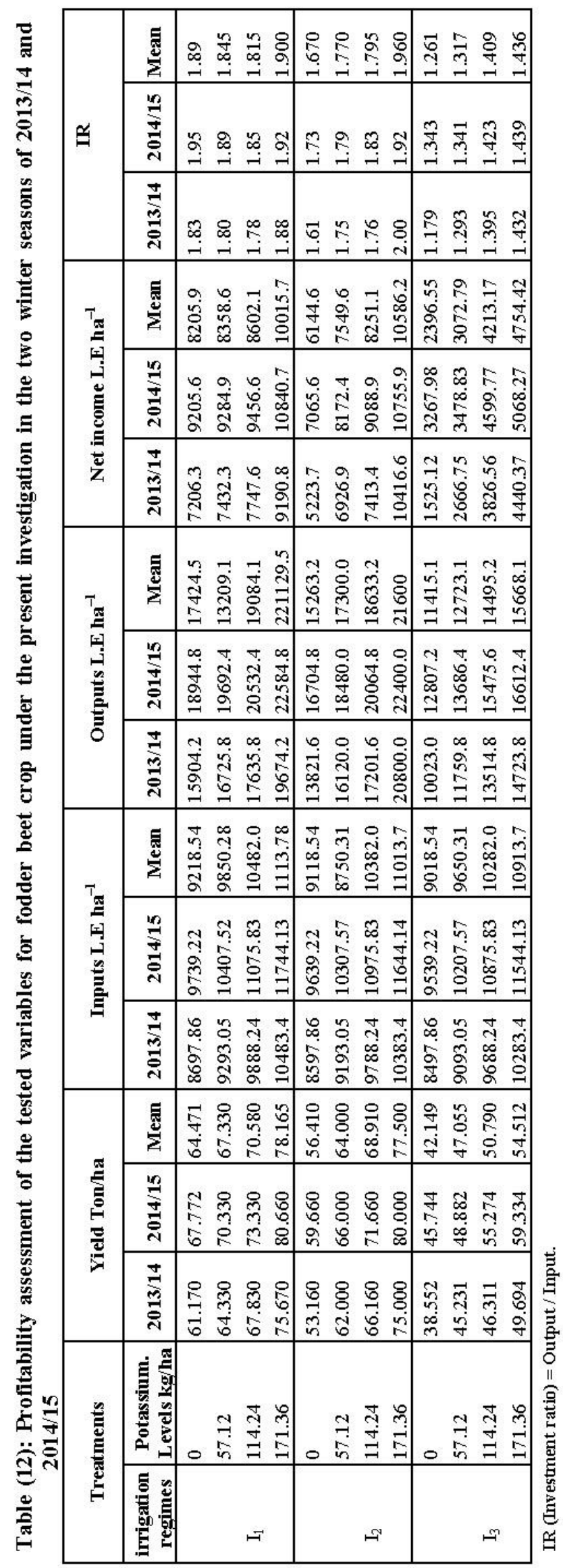




\section{REFERENCES}

Abdo Fatma, A. and N.A Anton, 2009. Physiological response of sesame to soil moisture stress and potassium fertilization in sandy soil. Fayoum J. Agric. Res \& De. 23(1):88111.

Akhtar, M.; M. Zubair,; M. Saeed, and R. Ahmed, (1993). Effect of planting geometry and water stress on seed yield and quality of spring planted sunflower (Helianthus annuus, L.). Pak. J. Agric. Sci. 30:73-76.

Amina I. EL-Shafey (2017). Response of soybean to water stress conditions and foliar application with salicylic and ascorbic acids. Zagazig J. Agric. Res., 44 (1) 1: 22.

Anton, N. A.; F. A. Abbas,; K. M. R. Yousef and 1. EL-Hyatemy,1995. Effect of Irrigation initials and potassium fertilization on fodder beet plants under calcareous soil Conditions. Egypt, J. App. Sci.; 10 (12) 404-454.

A.O.A.C. (1990) Official Methods of Analysis, 15th ed., Association of Official Analytical Chemists, Inc., Virginia, USA, 770-771.

Badr, N. M., Thalooth, A. T., Mohamed, M. H. (2004). Effect of foliar spraying with the nutrient compound "streen" on the growth and yield of sunflower plant subjected to water stress during various stages of growth. Bull. The Nati. Res. Con. Cairo, 29(4):427-439

Bahuri, S.S., A.A., Camal and A.A. Wiled, 2003. Effect of irrigation water amount and potassium fertilization on fodder beet yield and yield components under new reclaimed sandy soil conditions. Poc. $10^{\text {th }}$ Conf. Agron., Suez. Canal Univ. Fac. Envirorn. Agric. Sci., El Arish, Egypt, 2003.18-29

Black, C.A. (Ed.) (1965). Methods of soil Analysis, Parts and 2.Amer. soc. Agron No.9. Madioon. Wioconoin, USA.

Camp, C.R. (1998) subsurface drip irrigation: a review. Trans ASAE, 41 (5): 1353-1367, USA.

Church D.C. (1979) Digestive physiology and Nutrition of Ruminant, 1 Corvallis, O\&B Books Inc.

Doerenbos, J. and A. Kassam. (1979) yield response to water by, FAO irrigation and Drainage paper No. 33, Rome, Italy.

Egilla, J. N., Daries, F. T. and Drew, M.C. (2001): Effect of potassium on drought resistance of Hibiscus rosa-sinesis cv. Leprechaun: Plant growth, Leaf macro-and micronutrient content and root longevity. Plant soil, 229:213-224.
Foyer, C.H. and G. Noctor; (2000). Oxygen processing in photosynthesis: regulation and signaling. New photo. 146: 359-388.

Hall, A. J.; D. J. Conner; and D. M. Whitifield, (1990). Root respiration during grain filling in sunflower: The effect of water stress. Plant soil, 121:57-66.

Hasanuzzaman, M.; M. H. M. Borhannelddin, K. Kamrun, Md. H. Shahadat , A. Juhayer, Md. Shahadat , Abdul Awal M. Chowdhury, Moumita and Masayuki Fujita. (2018). Avital Regulator of plant Responses and Tolerance to Abiotic stresses. Agronomy Review 8, 31-29.

Hawksford, M.; W. Horst,; T. Kichy,; H. Lambers,; J. Schjoerring,; I. Skrumsager Moller, and P. White, (2012): Fuction of macronutrients In Marchner's Mineral $\mathrm{Nu}-$ trition of Highen plants, Marchner, P., Ed.;Academic press: London, U.K., 135189.

Human, J. J.; D. Dutoit; H. D. Bezuidenhout, and L. P. Bruyn,1990. The influence of plant water stress on net photosynthesis and yield of sunflower. Crop Sci., 164: 231-241.

Hussein. M. M. and Hanan S. Siam, 2014. Growth, yield and water use efficiency of fodder beet responses to the NPK fertilizer and withholding irrigation. J. of Sci. and Rese. (IJSR) 3(11):3117-3126.

James, L.G., 1988. Principles of farm irrigation system design. John Wiley and Sons, Inc., NY, USA.

Jensen M.E., 1983. Design and operation of farm irrigation systems, Amer. Soc. Agric. Eng. Michigan, USA, P. 827.

Kassab, O. M., S. A. Orabi, and A. A. Abdo Ellil, 2012. Physiological response to potassium application in fodder beet plant grown under water stress. Aust. J. of Bas. and Appl. Sci. 6(13):566-574.

Kramer, P.J. (1969). "Plant and Water Relationships. A Modern Synthesis", TATA. MacGraw-Hill Publishing Company Ltd., New Delhi. 482 pp.

Lazcano-Ferrat, I. and C. J. Lovatt, 1999. Relationship between relative water content, nitrogen pools and growth of phaseolus unlgaris, L. and P. acutifolius during water deficit. Crop Sci., 39(2):467-457.

Marschner, H., 2012. Marschner's Mineral Nutrition of Higher Plants, $3^{\text {rd }}$ ed.; Academic Press: London, U.K. 2012; 178-189.

Mary, E. N. Henen, 2011. Response of some sunflower to water stress and biofertilization. Ph. D. Thesis. Fac. of Agri. Alex. Univ. 
Mary E. Nashed, Engy S. Mohamed and Fadia M. Sultan (2019). Physiological response of fodder beet (Beta vulgaris, L.) to soil dressing of potassium Fertilization, Foliar Pray of Potassium and in combination under calcareous soil conditions. AmericanEurasian. J. Agric. \& Environ. Sci., 19(5):357-363.

Miseha, W. I.; M. F. Abdel Hamid and N. A. Anton (1992). Effect of water deficit on growth and yield of Fodder beet plant. Fifth Egyptian Botanical Conference, Saint Catherine, Sinai, Egypt. April 28-30, 1992, 195208.

Mong and Bugbe, 1992. Inherent limitation of nondestructive chlorophyll meters. A Comparison of types meters. Hort. Sci., 27:6971.

Pendleton, J. W. (1965). Increasing water use efficiency by crop management in: W.H. Pierre, D. Kirkham, J. Pesek and R. Shaw (Eds.). "Plant Environment and Efficient Water Use". Amer. Soc. Madison, Wisc. P.236-255.

Peterburgski A.V. (1968) Handbook of Agronomic Chemistry, Kolop Publishing House, Moscow, Russia.

Romheld, V. and E. A. Kirkby, 2010. Research on potassium in agriculture. Needs and prospects. Plant soil, 334:155-180.

Saad, El-Deen, A.W.M. (2006) Botanical studies on sesame plants (Sesamum indicum L.) grown under newly reclaimed soil as affected by irrigation intervals and hill spacing. The second conf. Farm Integrated Pest Management. Fac. Univ.,16-18 Jan.,84-99.

Sakr J.O., H.A. Awad, S.E. Seadh and W.A.E. Abido .2014. Influence of irrigation withholding and potassium levels on forge yields and its quality of fodder beet. J. Cro. Sci. 5(1):116-125.

SAS, .2014. SAS: Business Analytics and Business Intelligence Software. SAS Inst. http://www.sas.com/en_us/home.html.

Sgherri, C.L.M., C. Pinzino, and F. Navari-Izzo, .1996. Sunflower seedling subjected to increasing stress by water deficit: Changes in $\mathrm{O} 2$ production related to the composition of thylakoid membranes. Plant phys., 196(3):446-452.

Sinclair, T.R and M. M. Ludlow .1985. Who tought plants thermodynamics? The unfulfilled potential of plant water potential. Aust. J. plant physiol., 12: 213- 217.

Snedecor,G. W. and. W. C. Cochran, .1980. Statistical Methods, Oxford and IBH publishing 7th ed. Iowa State univ. Press, Iowa USA.

Steel, R.G. and J. H. Torrie .1980. Principles and Procedures of Statistics. Mc Graw Hill Inc., New York, USA.

Stokel, Co. and Kiniry, K.R (1990). Variability in crop radiation-use efficiency associated with vapour-pressure deficit. Field crop Res., 25:171-181.

Tang, Z. H. , A. J. Zhang, M. Wei,; X.G. Chen, Z. H. Liu, H. M. Li, and Y. F. Ding, .2015. Physiological response to potassium deficiency in three sweet potato (Ipomoea botatos, L.) genotypes differing in potassium utilization efficiency. Acta physiol. Plant. 37-184.

Tejada, M.; M. Hernandez and C. Garcia, .2006. Application of two organic amendments on soil restoration: Effect on the soil Biological properties. J. Envir Quality., 35: 10101017.

Terbea, M., A. V. Vranceamu, E. Percu, D.S. Craiciu, and G. Micut, .1995. Physiological response of sunflower plants to drought. Rom. Agric. Res., 3:61-67.

Thomas, T. C. and A. C. Tomas, .2009. Vital role of potassium in the osmatic mechanism of stomata aperture modulation and its link with potassium deficiency. Plant signal. Behav. 4:240-243.

Wang, M.; Q. Zheng; Q. Shen, S. Guo, .2013. The Critical role of potassium in plant stress response. Int. J. Mol. Sci. 14; 7370-7390.

Watson, D. J., .1952. The physiological basis of variation in yield. Adv. Agron., 4:101-

145.

Welch, L.F. and R.L. Flannery (1985). Potassium nutrition of corn. Potassium in Agriculture. Proceedings of an international Symposium held 7-10 July in Atlanta and Georgia. Edited by R. Munson, 647-663. 


\section{الاستجابة الفسيولوجية و انتاجية بنجر العلف لمعدلات الرى بالتنقيط ومستويات من التسميا البوتاسى تحت ظروف الاراضى الجيرية}

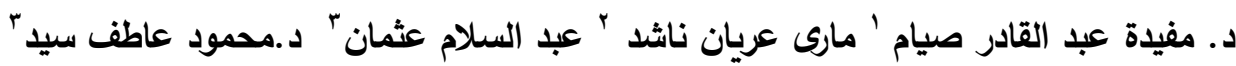

1-قسم بحوث محاصيل العلف - معهد بحوث المحاصيل الحقلية - مركز البحوث الزراعية .

r-قسم بحوث فسيولوجيا المحاصيل - معهد بحوث المحاصيل الحقلية - مركز البحوث الزراعية .

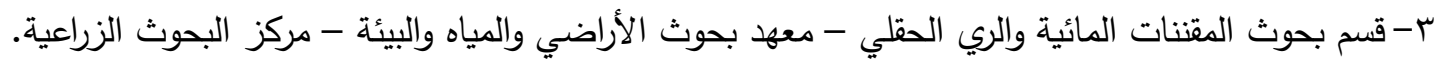

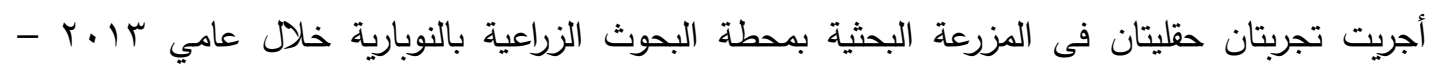

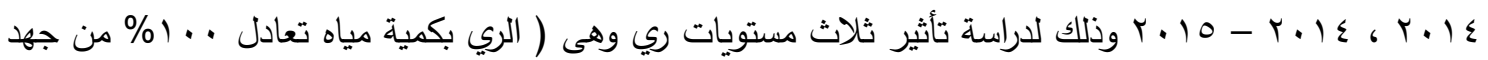

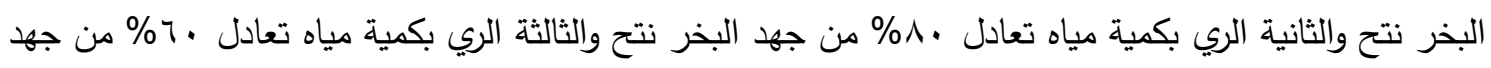

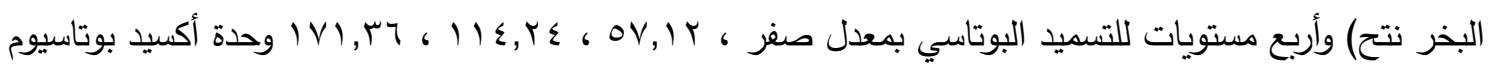

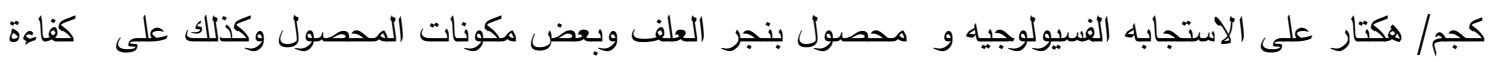

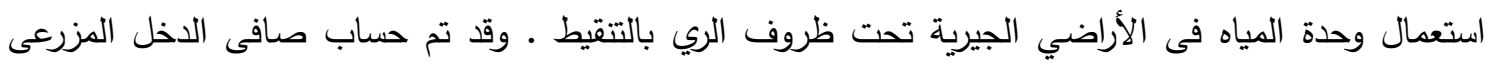

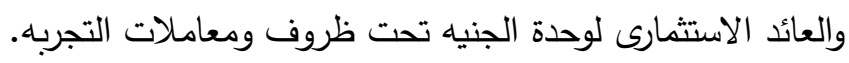

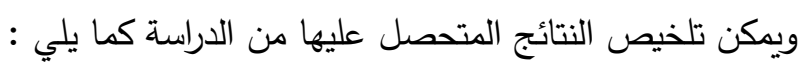

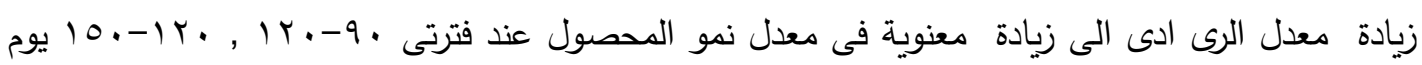

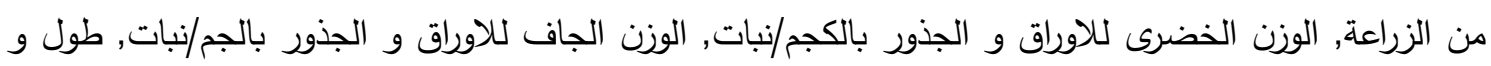

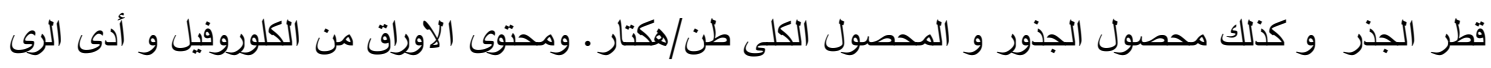

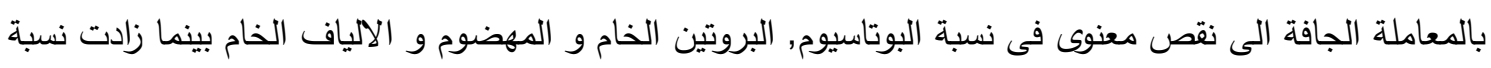

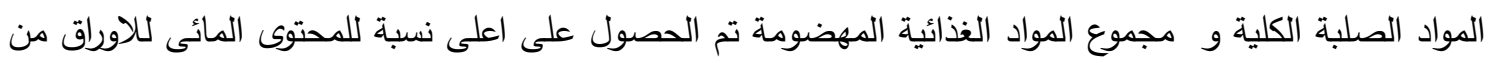
معاملة الرى الرطبة, بينما ادت المعاملة .یر\% من البخر نتح الى الحصول على العلى العلى قيمة لمعدل استخدام المياه.

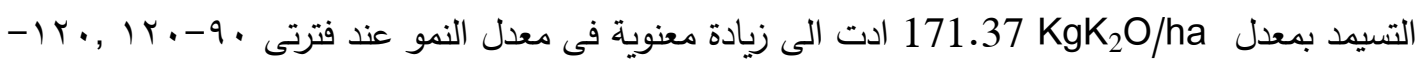

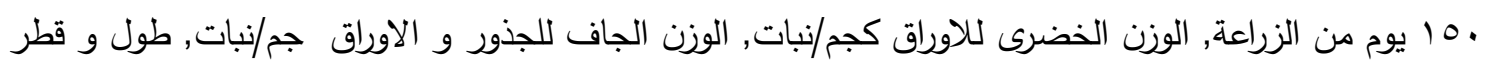

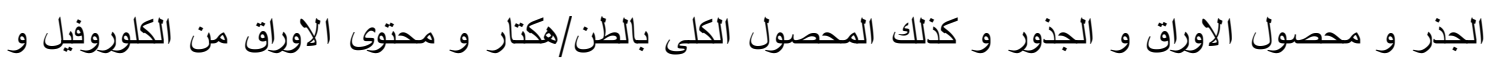
ايضا البروتين المهضوم و نسبة البوتاسيوم. عند التسميد بمعدل 114.24 KgK معنوية فى الوزن الخضرى للجذور بالكجم/نبات و البروتين الخام و الالياف الخام بدون فرق معنوى بينهم. بينما

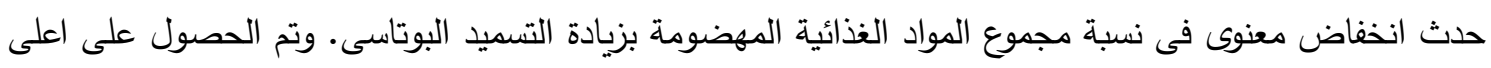
قيم للمحتوى المائى للاوراق و كذلك كفاءة استخدام المياه من التسميد بمعدل 171.36 KgK

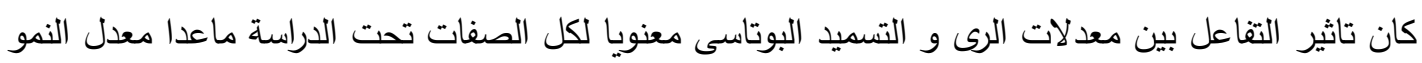

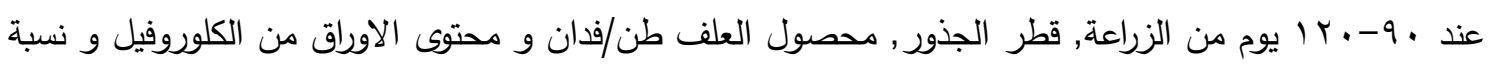

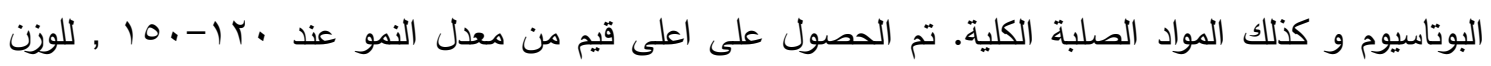
الخضرى للاوراق كجم/نبات, الوزن الجاف للاوراق و الجذور جم/نبات, البروتين الخام و كذلك الالياف الخام

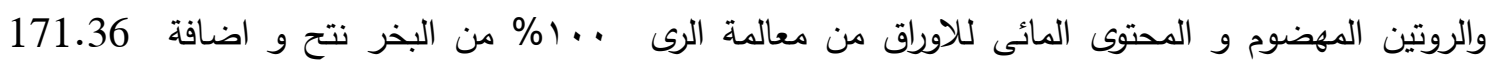
KgK 20

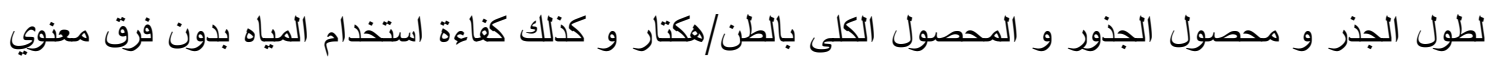

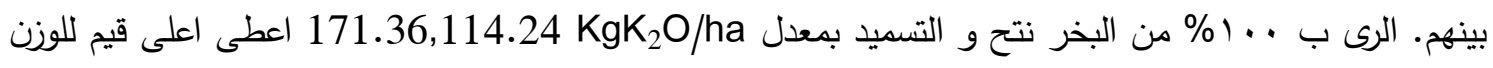


الخضرى للجذور كجم/نبات بدون فرق معنوى بينهم. بينما تم الحصول على اعلى قيم لل مجموع المواد الغذائية

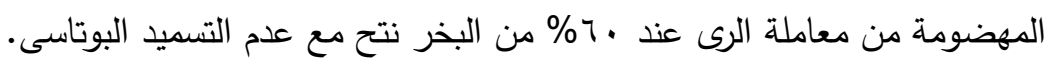

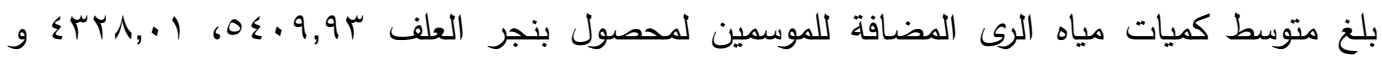

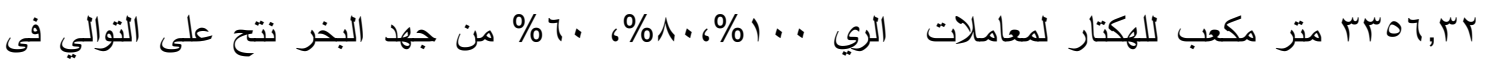
الأراضي الجيرية تحت نظام الري بالتتقيط

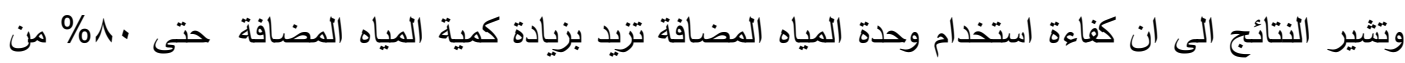

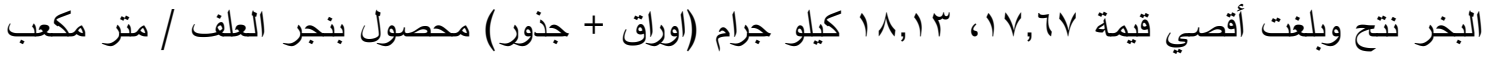

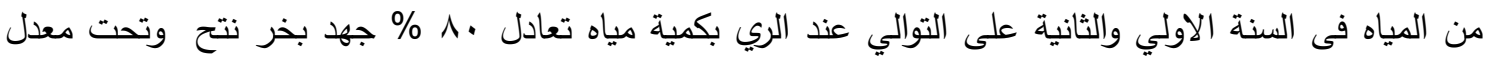

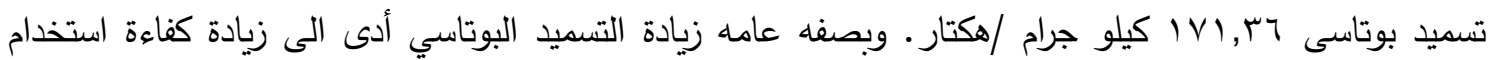

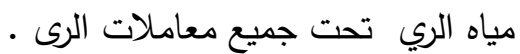

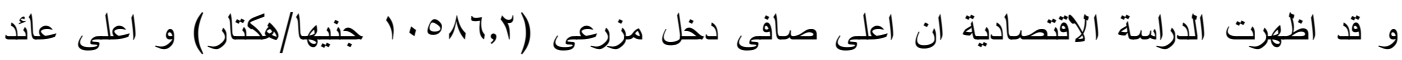

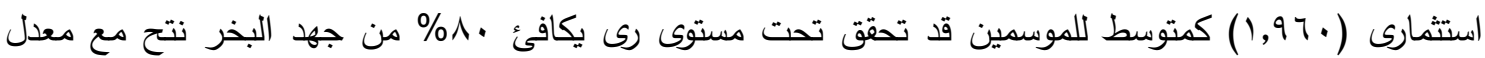

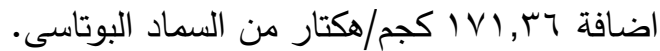
تشير النتائج السابقة بأنه تحت ظروف الاراضى الجيرية والرى بالتنقيط وتحت ظروف التجربة الى أمكانية

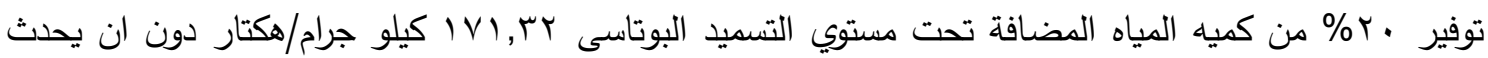
نقص معنوى فى محصول بنجر العلف. 